\title{
Mechanisms and Regulation of Cardiac Cav1.2 Trafficking
}

\author{
Maartje Westhoff and Rose E. Dixon *
}

check for

updates

Citation: Westhoff, M.; Dixon, R.E. Mechanisms and Regulation of Cardiac Cav1.2 Trafficking. Int. J. Mol. Sci. 2021, 22, 5927. https://doi.org/ $10.3390 /$ ijms 22115927

Academic Editor: Brian P. Delisle

Received: 5 May 2021

Accepted: 29 May 2021

Published: 31 May 2021

Publisher's Note: MDPI stays neutral with regard to jurisdictional claims in published maps and institutional affiliations.

Copyright: (c) 2021 by the authors. Licensee MDPI, Basel, Switzerland. This article is an open access article distributed under the terms and conditions of the Creative Commons Attribution (CC BY) license (https:// creativecommons.org/licenses/by/ $4.0 /)$.
Department of Physiology and Membrane Biology, School of Medicine, University of California, Davis, CA 95616, USA; mfwesthoff@ucdavis.edu

* Correspondence: redickson@ucdavis.edu

\begin{abstract}
During cardiac excitation contraction coupling, the arrival of an action potential at the ventricular myocardium triggers voltage-dependent L-type $\mathrm{Ca}^{2+}\left(\mathrm{Ca}_{\mathrm{V}} 1.2\right)$ channels in individual myocytes to open briefly. The level of this $\mathrm{Ca}^{2+}$ influx tunes the amplitude of $\mathrm{Ca}^{2+}$-induced $\mathrm{Ca}^{2+}$ release from ryanodine receptors (RyR2) on the junctional sarcoplasmic reticulum and thus the magnitude of the elevation in intracellular $\mathrm{Ca}^{2+}$ concentration and ultimately the downstream contraction. The number and activity of functional $\mathrm{Ca}_{\mathrm{V}} 1.2$ channels at the $\mathrm{t}$-tubule dyads dictates the amplitude of the $\mathrm{Ca}^{2+}$ influx. Trafficking of these channels and their auxiliary subunits to the cell surface is thus tightly controlled and regulated to ensure adequate sarcolemmal expression to sustain this critical process. To that end, recent discoveries have revealed the existence of internal reservoirs of preformed $\mathrm{Ca}_{\mathrm{V}} 1.2$ channels that can be rapidly mobilized to enhance sarcolemmal expression in times of acute stress when hemodynamic and metabolic demand increases. In this review, we provide an overview of the current thinking on $\mathrm{Ca}_{\mathrm{V}} 1.2$ channel trafficking dynamics in the heart. We highlight the numerous points of control including the biosynthetic pathway, the endosomal recycling pathway, ubiquitination, and lysosomal and proteasomal degradation pathways, and discuss the effects of $\beta$-adrenergic and angiotensin receptor signaling cascades on this process.
\end{abstract}

Keywords: L-type calcium channels; ion channel trafficking; t-tubule; caveolae; calcium signaling; $\beta$-adrenergic receptor; angiotensin II

\section{Introduction}

Voltage-gated, L-type $\mathrm{Ca}_{\mathrm{V}} 1.2$ channels play an essential role in cardiac excitationcontraction (EC) coupling and can regulate cardiac gene expression. The number and activity of voltage-gated, L-type $\mathrm{Ca}_{\mathrm{V}} 1.2$ channels localized to specialized dyadic regions of the $t$-tubule sarcolemma, adjacent to ryanodine receptor (RyR2) clusters, dictates the degree of $\mathrm{Ca}^{2+}$ influx into cardiomyocytes and is thus a major determinant of the magnitude of ventricular contraction. On the other hand, $\mathrm{Ca}_{V} 1.2$ channels localized to caveolae are thought to play a critical role in regulation of gene expression in a process known as excitation-transcription coupling. Targeting of $\mathrm{Ca}_{V} 1.2$ channels to the appropriate membrane compartment is thus critical for their proper physiological function. The number of Cav1.2 channels at the sarcolemma at any given time is governed by the relative amount of channel insertions achieved with anterograde trafficking via the secretory and recycling pathways, versus endocytosis via retrograde trafficking pathways. Endocytosed channels can refuel recycling endosome pathways to provide a rapidly mobilizable pool of channels, or they can be targeted for degradation in lysosomes or the proteasome. In this review, we summarize the current literature on $\mathrm{Ca}_{\mathrm{V}} 1.2$ channel trafficking and its regulation. We highlight recent data indicating that G-protein coupled receptor (GPCR)-signaling can positively (in the case of $\beta$-adrenergic receptors) or negatively (in the case of Angiotensin type 1 receptors; $\mathrm{AT}_{1} \mathrm{R}$ ) influence the surface abundance of $\mathrm{Ca}_{\mathrm{V}} 1.2$ channels, providing a means to tune cardiac EC-coupling by altering channel expression. We begin with a brief summary of the structure and function of these multimeric channels. 


\section{Cav1.2 Channel Structure and Function}

\section{1. $C a_{V} \alpha$ Subunits}

L-type $\mathrm{Ca}^{2+}$ channels (LTCC) are a family of voltage-gated $\mathrm{Ca}^{2+}$ channels $\left(\mathrm{Ca}_{\mathrm{V}} 1.1-1.4\right)$ that allow $\mathrm{Ca}^{2+}$ influx into excitable cells in response to depolarization. Their structure and function is reviewed extensively elsewhere [1-3]. Here we focus on trafficking and regulation of $\mathrm{Ca}_{\mathrm{V}} 1.2$, a multimeric protein complex composed of a pore-forming $\alpha_{1}$ subunit encoded by cacna1c, and associated auxiliary subunits $\mathrm{Ca}_{\mathrm{V}} \beta, \mathrm{Ca}_{\mathrm{V}} \alpha_{2} \delta$ and sometimes, $\mathrm{Ca}_{V} \gamma$ [1]. Cav $\alpha_{1 C}$ subunits are widely expressed in brain, smooth muscle, and pancreas, and they form the core of the most prevalent L-type $\mathrm{Ca}^{2+}$ channel in the cardiac muscle of the heart $[4,5]$. Underscoring their fundamental importance in cardiac function, cacna1c knockout is embryonic lethal in mice [6]. The typical structure of the Cav1.2 channel complex is depicted in Figure 1. When expressed alone, $\mathrm{Ca}_{V} \alpha_{1 C}$ subunits are not efficiently inserted into the membrane resulting in very low current density [7-9]. The full functional identity of the channel becomes evident once associated with its auxiliary subunits.

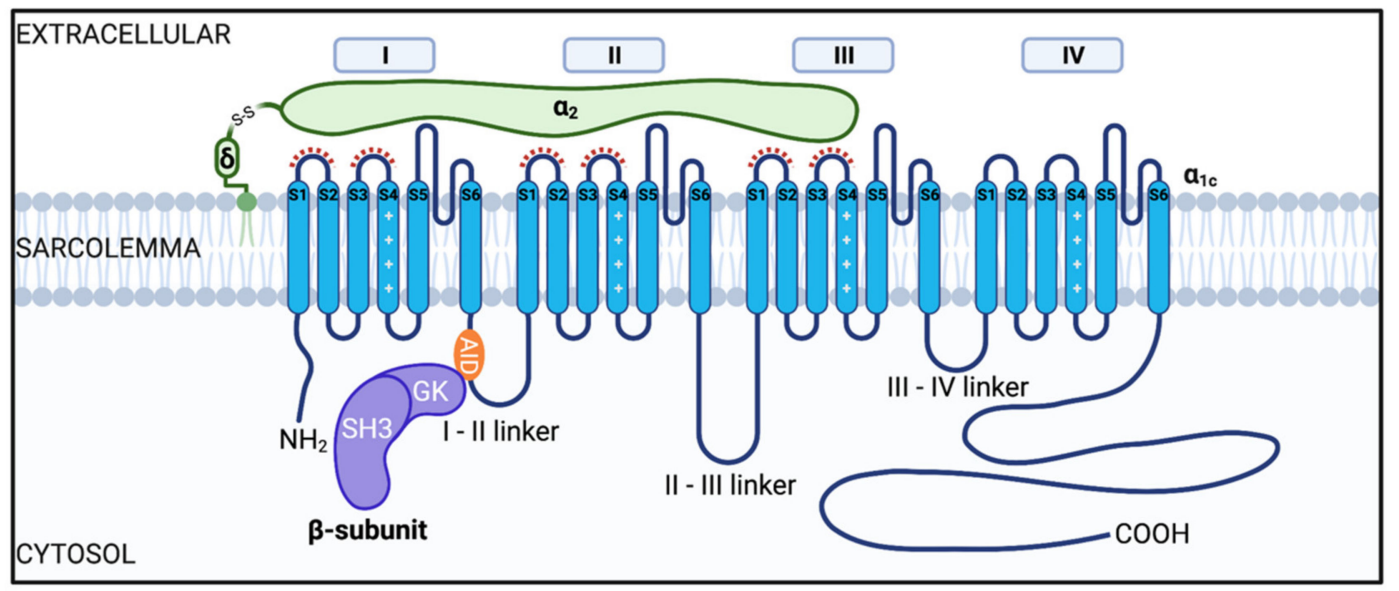

Figure 1. Illustration of the cardiac voltage gated L-type $\mathrm{Ca}_{V} 1.2$ channel complex. The channel consists of a pore-forming $\mathrm{Ca}_{V} \alpha_{1 \mathrm{C}}$ subunit and auxiliary subunits $\mathrm{Ca} \mathrm{a}_{V} \beta$ and $\mathrm{Ca}_{V} \alpha_{2} \delta$. The $\mathrm{Ca}_{V} \alpha_{1 \mathrm{c}}$ is composed of four homologous repeat domains (I-IV), each having six transmembrane spanning segments (S1-S6, shown in blue). S1-S4 comprise the voltage sensing domain (VSD) and S5-S6 form the pore domain (PD). Ca $\beta$ subunits (depicted in purple) are composed of a SH3, HOOK, and GK domain. Interaction of $\mathrm{Ca}_{V} \beta$ with the $\mathrm{Ca}_{V} \alpha_{1} \mathrm{c}$ occurs between the GK domain on $\mathrm{Ca}_{V} \beta$ subunits and the alpha interaction domain (AID) on the I-II linker (orange). $\mathrm{Ca}_{V} \alpha_{2} \delta$ subunits are proposed to interact with the extracellular loops of domains I-III as highlighted by the red dashed lines [10-13].

\section{2. $C a_{V} \beta$ Subunits}

$\mathrm{Ca}_{\mathrm{V}} \beta$ subunits are cytosolic proteins with Src homology 3 (SH3), HOOK, and guanylate kinase (GK) domains forming the core of the protein responsible for the majority of functional properties of the $\beta$ subunits [14-17]. There are four main $\mathrm{Ca}_{V} \beta$ subunits $\left(C a_{V} \beta 1-4\right)$ encoded by separate genes with several splice variants. $C_{a} \beta_{2 b}$ is the most highly expressed isoform in the heart [9]. Accordingly, $\mathrm{Ca}_{\mathrm{V}} \beta_{2}{ }^{-/}$mice suffer embryonic lethality and disrupted cardiac phenotype [18]. In heterologous and native systems interactions between $\mathrm{Ca}_{V} \beta$ and $\mathrm{Ca}_{V} \alpha_{1 \mathrm{c}}$ subunits lead to alterations in channel activation and inactivation as well as robust increases in surface expression and current density, likely due to an increased open probability and/or enhanced cell membrane localization of the channel complex [9,19-23]. This 1:1 stochiometric interaction between the subunits is thought to occur within the $\alpha$-interaction domain (AID), located within the I-II pore loop of $\mathrm{Ca}_{V} \alpha_{1 \mathrm{c}}$ subunits $[21,24]$, and small region of the GK domain on $\mathrm{Ca}_{V} \beta$, referred to as the AID-binding pocket (ABP) [16]. Mutations within this region interfere with $\mathrm{Ca}_{V} \beta$ and $\mathrm{Ca}_{\mathrm{V}} \alpha_{1 \mathrm{c}}$ interactions and result in diminished membrane targeting of $\mathrm{Ca}_{\mathrm{V}} \alpha_{1 \mathrm{c}}$ [21]. Furthermore, deletion mutants of regions within the $\mathrm{Ca}_{V} \alpha_{1 \mathrm{c}} \mathrm{C}$-terminus result in reduced 
plasma membrane localized channels, with many channels remaining stuck in internal membranes [25].

\section{3. $C a_{V} \alpha_{2} \delta$ Subunits}

$\mathrm{Ca}_{V} \alpha_{2} \delta$, is comprised of two subunits $\alpha_{2}$ and $\delta$ which are encoded by the same gene and bound together by disulfide bonds. The $\mathrm{N}$-terminal $\alpha_{2}$ region is extracellular, with the $\delta$ region anchored to the outer leaflet of the plasma membrane via a GPI anchor [26]. Of the several isoforms, $\mathrm{Ca}_{V} \alpha_{2} \delta 1-3$ have been found in the heart $[27,28]$. Within all the isoforms there is a Von Willebrand factor-A (VWA) domain in the extracellular region, and in $\mathrm{Ca}_{V} \alpha_{2} \delta_{1}$ and $\mathrm{Ca}_{\mathrm{V}} \alpha_{2} \delta_{2}$ this consists of a metal-ion-dependent adhesion site (MIDAS) which is thought to interact directly with the extracellular loops of $\mathrm{Ca}_{\mathrm{V}} \alpha_{1 \mathrm{c}}[11,29]$. When this MIDAS site is mutated, there is a diminished trafficking response and retention of the subunits within the ER [29]. As well as promoting trafficking of the channel complex, association of $\mathrm{Ca}_{\mathrm{V}} \alpha_{2} \delta$ with $\mathrm{Ca}_{\mathrm{V}} \alpha_{1 \mathrm{c}}$ also enhances the voltage-dependent activation by increasing the voltage sensitivity of the VSDs, allowing for calcium influx at more physiological membrane potentials [10].

\section{4. $\mathrm{Ca} a_{V} \gamma$ Subunits}

The final auxiliary subunit, $\gamma$, is composed of four transmembrane spanning segments with intracellular $\mathrm{N}$ - and C-termini. This is the least studied auxiliary subunit of cardiac $\mathrm{Ca}_{\mathrm{V}} 1.2$ channels but of the eight isoforms of $\gamma$ subunits, four have been shown to be expressed in cardiac tissue and to associate with the $\mathrm{Ca}_{V} 1.2$ complex $\left(\mathrm{Ca}_{V} \gamma 4, \mathrm{Ca}_{V} \gamma 6\right.$, $\mathrm{Ca}_{V} \gamma 7$ and $\mathrm{Ca}_{v} \gamma 8$ ). In HEK293 cells coexpression of $\mathrm{Ca}_{V} \alpha_{1 \mathrm{c}}$ with the various $\mathrm{Ca}_{v} \gamma$ subunits results in altered activation and inactivation kinetics of the whole cell $\mathrm{Ca}^{2+}$ current $\left(I_{\mathrm{Ca}}\right)[30]$. However, the specific role of endogenous $\mathrm{Cav}_{\mathrm{V}} \gamma$ subunits in native heart tissue and their effects on channel trafficking remain unknown.

\section{Trafficking of Cav1.2 Channels}

\subsection{Anterograde Transport of $C a_{V} 1.2$ to the Sarcolemma}

$\mathrm{Ca}_{\mathrm{V}} \alpha_{1 \mathrm{c}}$, like all proteins destined for the cell membrane, is synthesized by membranebound ribosomes on the rough endoplasmic reticulum (rER) [31]. This is the first step in the classical secretory pathway. Briefly, free ribosomes initially pick-up the mRNA for the channel in the cytosol and begin translation but this is paused once the ribosome translates a signal sequence, A.K.A. the leader sequence. This is a short, $\sim 20$ amino acid long chain of hydrophobic amino acids near the N-terminus of the polypeptide, that once translated, finds and binds a signal recognition particle (SRP) that initiates targeting of the entire complex to the rER membrane. This idea was originally proposed by Blobel and Sabatini in their 'signal hypothesis' [32]. Recognition and binding of the signal sequence and ribosome by the SRP puts a halt to translation until the SRP binds to an SRP receptor. Once situated on the rER membrane, the SRP is released and the ribosome and polypeptide are handed off to a protein translocation complex (Sec61) where translation resumes. The Sec61 translocon complex forms an ER membrane spanning channel that acts as a conduit for entry of the growing polypeptide chain into the ER [33]. Since $\mathrm{Ca}_{V} \alpha_{1 c}$ is a transmembrane protein bound for the plasma membrane, it is directly inserted into the ER membrane as it forms, with the $\mathrm{N}$ and C-termini located within the cytosol, the extracellular loops in the ER lumen, and the hydrophobic transmembrane regions spanning the ER membrane. $\mathrm{Ca}_{V} \alpha_{2} \delta$ and $\mathrm{Ca}_{V} \gamma$ are similarly produced while cytosolic proteins like $\mathrm{Ca}_{V} \beta$ subunits lack signal sequences and are thus translated on free ribosomes and released directly into the cytosol. Whether the entire channel complex assembles in the ER membrane remains unclear but there is a school of thought suggesting that binding of at least $\mathrm{Ca}_{\mathrm{V}} \beta$ to $\mathrm{Ca}_{\mathrm{V}} \alpha_{1 \mathrm{c}}$ is necessary to release the channels from the ER and promote forward trafficking (discussed in more detail below). Upon their exit, the channels move in vesicles onwards to the Golgi apparatus, subsequently exiting from trans-Golgi complex in vesicles that are propelled by 
kinesin motor proteins along microtubule highways to their t-tubular, caveolar, or surface sarcolemmal destinations (see Figure 2).

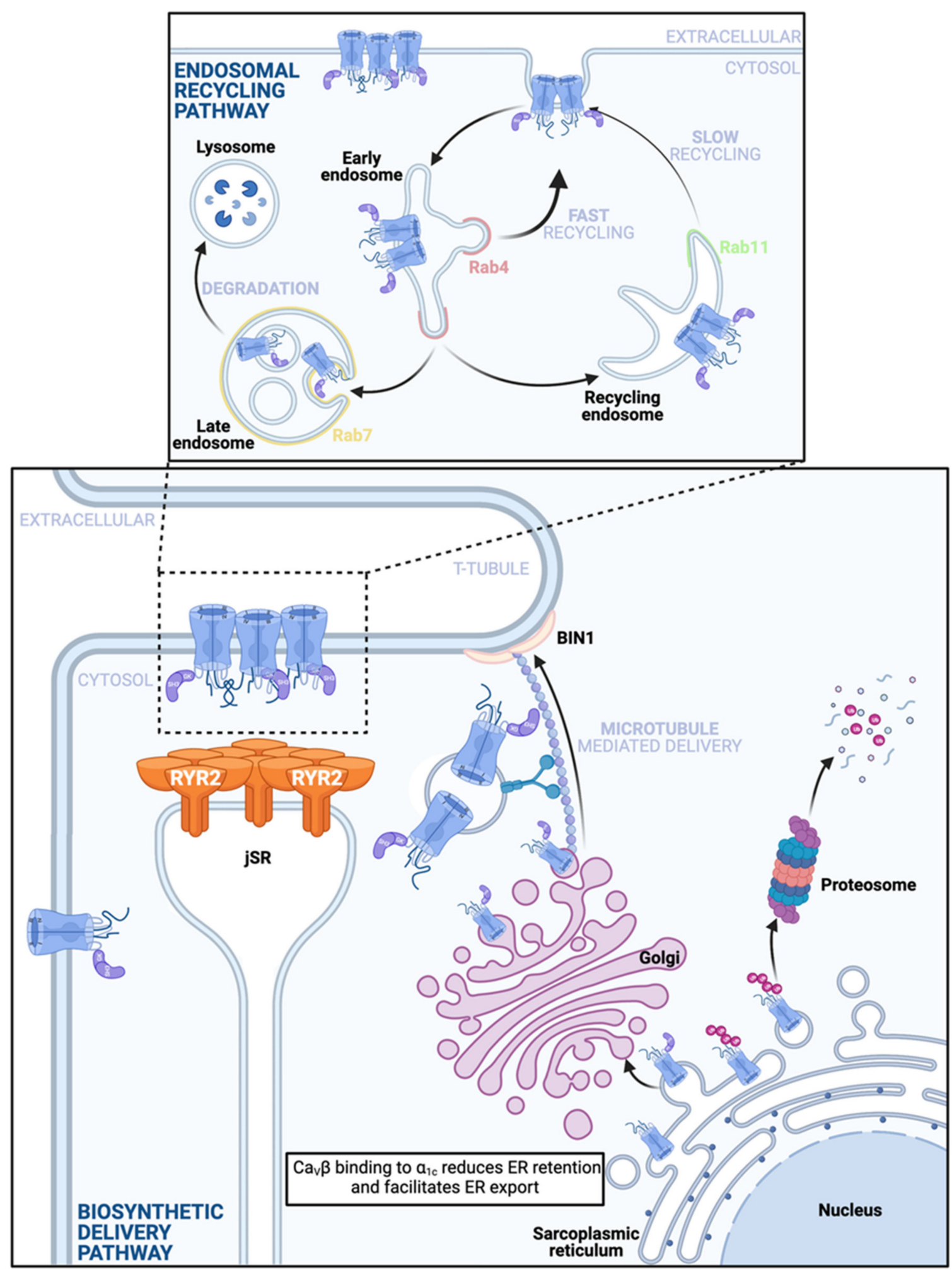

Figure 2. Anterograde $\mathrm{Ca}_{\mathrm{V}} 1.2$ channel delivery pathways. Bottom: A depiction of the 'Biosynthetic Delivery Pathway' that commences when $\mathrm{Ca}_{V} \alpha_{1 \mathrm{c}}$ are translated directly into the rER membrane. These pore-forming subunits have several ER retention motifs and just one identified ER export motif. Binding of the $\mathrm{Ca}_{\mathrm{V}} \beta$ subunit to the $\mathrm{Ca}_{\mathrm{V}} \alpha_{1 \mathrm{c}}$ while in the ER membrane is thought 
to lessen the influence of the retention signals and favor channel export, whereby the channels subsequently exit the ER in vesicles to the Golgi complex. Absence of the $\mathrm{Ca}_{\mathrm{V}} \beta$ subunit may render the channels more vulnerable to ubiquitination on the ER membrane, precipitating proteosomal degradation. Note this vulnerability has been reported in neuronal CaV 1.2 and has not yet been confirmed in the cardiac channels. Single or clustered channels exit the trans-Golgi network (TGN) and are carried along microtubules by motor proteins to BIN1-anchored delivery hubs on the $\mathrm{t}$-tubule sarcolemma to assume positions in dyadic and caveolar regions. It is unclear exactly when and where in the anterograde trafficking pathway $\mathrm{Ca}_{V} \alpha_{2} \delta$ joins the complex. Top: Stable sarcolemmal Cav 1.2 channel expression is maintained in the face of ongoing channel internalization by the endosomal recycling pathway. Endocytosed channels enter the early endosome and are sorted, a subpopulation is sent to Rab7 positive late endosomes and may subsequently undergo lysosomal degradation. The remainder of the channels are recycled back to the membrane either through a fast, direct pathway from the early endosome along a Rab4-dependent fast recycling pathway, or through a slower Rab11-dependent recycling pathway from the recycling endosome. If some channels are degraded, it is possible that endosomal reservoirs of channels take their place and supplement this pathway to maintain stable membrane expression.

\subsection{Role of the $\mathrm{Ca} a_{V} \beta$-Subunit in $\mathrm{C} a_{V} 1.2$ Trafficking}

Until very recently, the prevailing thought was that $\mathrm{Ca}_{V} \beta$ subunit interactions with $\alpha_{1 \mathrm{c}}$ were indispensable for channel trafficking to the cardiomyocyte surface membrane where the channels fulfill a duality of functions at the t-tubules in triggering $\mathrm{Ca}^{2+}$ induced $\mathrm{Ca}^{2+}$ release from RyR2, and contributing to loading of the SR [34], and play a further role at the caveolae in activation of calcineurin-NFAT signaling pathways [35]. The role of the $\mathrm{Ca}_{V} \beta$-subunit in membrane targeting of the channels has been extensively reviewed elsewhere [36,37] and so we mention it only briefly here to highlight some more recent advances $[38,39]$. In heterologous expression systems and in neurons, interactions between $\beta$-subunits and $\alpha_{1}$ are fundamentally required for channel trafficking to the plasma membrane [7,19,24,40-44]. Expression of the $\alpha_{1}$ subunit alone in the absence of the $\beta$-subunit, yields dramatically reduced surface expression and little to no currents, in contrast to the robust surface expression and currents in cells in which the $\beta$-subunit is co-expressed $[19,23,43,45-47]$. This effect is abrogated by mutations in the AID or the ABP suggesting that it requires $\mathrm{Ca}_{\mathrm{V}} \beta$ binding to the AID on the I-II loop of $\mathrm{Ca}_{V} \alpha_{1}$ [48-50]. It was initially suggested that this interaction shielded an ER retention motif on the I-II loop and thus promoted enhanced exit of the channel from the ER and on through the anterograde trafficking pathway to the surface membrane [51]. However, this idea was later refuted in work from the Colecraft lab that used chimeric channel constructs in which various intracellular portions of $\mathrm{Ca}_{V} \alpha_{1 \mathrm{c}}$ were substituted into another calcium channel (the $\alpha_{1 \mathrm{~g}}$ of $\mathrm{Ca}$ (3.1) known to exhibit $\mathrm{Ca}_{\mathrm{V}} \beta$-independent surface expression [23]. In this paradigmshifting study, it was revealed that the I-II loop actually contains an ER-export signal whereas all the other intracellular loops and the $\mathrm{N}$ - and $\mathrm{C}$-termini contain ER-retention signals. It is thus thought that binding of the $\mathrm{Ca}_{V} \beta$ to the AID induces a conformational change in the channel that weakens the ER retention influences and instead shifts the balance toward ER export and trafficking to the surface. Furthermore, in heterologous expression systems and hippocampal neurons, binding of $\mathrm{Ca}_{V} \beta$ to $\mathrm{Ca} \mathrm{V}_{\mathrm{V}} \alpha_{\mathrm{c}}$ in the ER, reportedly protects the channel from ubiquitination and proteosomal degradation [52].

In cardiomyocytes the cellular architecture is vastly different from that of heterologous cells, but until recently, the same principals and reliance on the $\mathrm{Ca}_{\mathrm{V}} \beta$-subunit for surface trafficking were thought to apply, in part fueled by studies showing that short hairpin RNA-mediated knockdown of $\mathrm{Ca}_{\mathrm{V}} \beta_{2}$ reduced $I_{\mathrm{Ca}}$ in adult rat ventricular myocytes by $\sim 60 \%$ [53], and others showing that $\mathrm{Ca}_{\mathrm{V}} \beta_{2}{ }^{-1-}$ mice succumbed to embryonic lethality at around E10.5 due to heart failure caused by reduced L-type calcium current [18]. Marx and colleagues have cast doubt on the reliance of cardiac $\mathrm{Ca}_{\mathrm{V}} \alpha_{1 \mathrm{c}}$ on $\mathrm{CaV}_{\mathrm{V}} \beta$ for trafficking in a study where they generated transgenic mice that expressed WT CaV $\alpha_{1 c}$ and could be doxycycline-induced to additionally express dihydropyridine (DHP)-resistant $\mathrm{Ca}_{\mathrm{V}} \alpha_{1 \mathrm{c}}$ with a triple alanine mutation in their AID that significantly decreases the affinity of $\mathrm{Ca}_{V} \beta$-binding [44]. The AID mutant channels did not co-immunoprecipitate (co-IP) with $\mathrm{Ca}_{V} \beta$ but did display t-tubule localization and generated whole-cell $\mathrm{Ca}^{2+}$ currents that could be distinguished from WT channels with addition of the DHP nisoldipine. This study raises questions about the role of $\mathrm{Ca}_{\mathrm{V}} \beta$ in $\mathrm{Ca}_{\mathrm{V}} \alpha_{1 \mathrm{c}}$ trafficking in cardiomyocytes, 
however, the interpretation of these results is complicated by the presence of WT channels. Work from our lab reveals that $\mathrm{Ca}_{\mathrm{V}} 1.2$ channels often insert into the sarcolemma as large, multi-channel clusters [54]. In addition, we and others have shown that $\mathrm{Ca}_{V} 1$ channels can functionally interact within clusters, such that the conformational change in one channel that occurs upon gating, can be transmitted to adjacent interacting channels, triggering their coordinate opening [55-64]. With this in mind, it seems possible that the conformational change induced by $\mathrm{Ca}_{\mathrm{V}} \beta$ subunits binding to WT channels, could be conferred to $\beta$-less AID mutant channels in the cluster and that this allows those channels to escape the ER and traffic to the sarcolemma. This was partially addressed by Marx et al. with experiments performed in a heterologous expression system, where they expressed WT channels and DHP-insensitive WT or DHP-insensitive AID mutant channels. Addition of nisoldipine resulted in remaining $I_{\mathrm{Ca}}$ in the DHP-insensitive WT case and almost eliminated $I_{\mathrm{Ca}}$ in the DHP-insensitive AID mutant channels. The conclusion was that $\mathrm{Ca}_{\mathrm{V}} \beta$-less channels could not hitch a ride with WT channels in tsA cells. To unequivocally dispel the $\mathrm{Ca}_{\mathrm{V}} \beta-\mathrm{Ca}_{\mathrm{V}} \alpha_{1 \mathrm{c}}$ trafficking hypothesis, a transgenic mouse that expresses only AID mutant channels would be the gold standard. Nevertheless, this study also revealed that $\mathrm{Ca}_{\mathrm{V}} \beta$-less channels are refractory to $\beta$-adrenergic stimulation and formed the prelude to the ground-breaking discovery that binding of the small Ras-like $G$ protein Rad to $C a_{V} \beta$ on the $C a_{V} 1.2$ channel complex, partially inhibits channel activity until Rad it is phosphorylated by PKA, causing it to dislodge from $\mathrm{Ca}_{V} \beta$ and revealing the enhanced open probability attributed to adrenergic regulation of these channels [39].

\section{3. $\mathrm{C} a_{V} 1.2$ Recycling}

Membrane protein expression is maintained in the face of ongoing endocytosis by both delivery via the biosynthetic pathway and from the endosomal recycling pathway (see Figure 2). Rab GTPases choreograph the trafficking of vesicular cargo from the membrane, through endocytosis, sorting, and subsequent recycling or degradation [65]. The $>60$-member family of Rab proteins is the largest family in the superfamily of Ras small GTPases. These proteins regulate the tethering or docking of vesicles to different membrane and endomembrane compartments, and may play roles in transport of vesicles along different cytoskeletal filaments by interacting with specific motor proteins [66]. For example, insulin reportedly stimulates Rab4 activity and association with the motor protein kinesin II (KIF3) to facilitate microtubule-mediated delivery and plasma membrane insertion of the GLUT4 glucose transporter in 3T3-L1 adipocytes [67]. Rab4 is known to facilitate so-called 'fast recycling' ( $\mathrm{t}_{1 / 2}=1-5 \mathrm{~min}$ ) of vesicular cargo from early endosomes back to the plasma membrane $[68,69]$. Rab11 is another Rab protein which is known to facilitate 'slow recycling' ( $t_{1 / 2}=12-30 \mathrm{~min}$ ) of vesicular cargo from recycling endosomes back to the plasma membrane $[68,69]$, and reportedly interacts with actin-filament associated myosin $\mathrm{V}$ motor proteins [70]. In the heart, the role of Rab protein interactions with cytoskeletal elements in $\mathrm{Ca}_{\mathrm{V}} 1.2$ channel recycling has not yet been investigated but our recent work suggests the presence of three endosomal reservoirs of $\mathrm{Ca}_{\mathrm{V}} 1.2$ channels located on: (1) Rab4-positive early endosomes, (2) Rab11-positive recycling endosomes, and (3) Rab7-positive late endo/lysosomes [54]. This recent work further provided the first reports of $\mathrm{Ca}_{\mathrm{V}} 1.2$ channel trafficking and recycling in live adult mouse ventricular myocytes [54]. This was achieved by transducing cardiomyocytes in vivo via retro-orbital injection with a cardiotropic AAV9-packaged, fluorescent protein-tagged Cav $\beta_{2}$ (AAV9$\mathrm{Ca}_{\mathrm{V}} \beta_{2}$-paGFP) which essentially served as a fluorescent 'biosensor' to enable monitoring of the localization and dynamics of a portion of the endogenous channels. Total internal reflection fluorescence (TIRF) imaging using an $\sim 150 \mathrm{~nm}$ evanescent field of excitation light, allowed examination of channel dynamics in the surface sarcolemma and initial portion of the t-tubular membrane in isolated, transduced cardiomyocytes, and revealed ongoing, rapid insertion and removal of channels $[54,59]$ that likely reflects delivery from both the biosynthetic and recycling pathways, and counterbalancing endocytosis. Often these insertion and removal events involved entire clusters of channels although smaller 
discrete events that may represent removal of individual channels were also observed. The arrival and departure of channel clusters implies that $\mathrm{Ca}_{\mathrm{V}} 1.2$ channels can cluster in intracellular compartments. This idea was corroborated by immunostaining experiments that revealed clusters of channels on endosomes, and others lined-up in vesicles along microtubules. In agreement with the previously reported $\sim 3 \mathrm{~h}$ lifetime of plasma membrane Cav1.2 channels [19], $2 \mathrm{~h}$ cytoskeletal disruption with nocodazole, latrunculin A, or a combination thereof, produced no change in $I_{\mathrm{Ca}}$ density measured with whole-cell patch clamp electrophysiology, or in the overall expression of sarcolemmal channels assessed with super-resolution microscopy of immunostained channels. While this study did not explicitly examine the role of the cytoskeleton in ongoing (unstimulated) $\mathrm{Ca}_{\mathrm{V}} 1.2$ channel insertion and endocytosis, a previous study in tsA-201 cells using TIRF-fluorescence recovery after photobleaching (TIRF-FRAP) revealed a significant deficit in channel delivery to the membrane when microtubules, actin, or both were pharmacologically disrupted, and intracellular dynamics of vesicular $\mathrm{Ca}_{V} 1.2$ was largely halted by these treatments [58]. With regards to the dependence of Cav 1.2 endosomal recycling on the cytoskeleton, in HL-1 cells Rab11a-mediated recycling of $\mathrm{Ca}_{\mathrm{V}} 1.2$ channels occurs along actin filaments whereas Rab4-dependent fast recycling is thought to occur along microtubules [71]. Thus, a model of Cav1.2 channel recycling is beginning to emerge as illustrated in Figure 2.

\subsection{Endocytosis and Retrograde Transport of $\mathrm{C} a_{V} 1.2$}

There remains a distinct absence of studies on $\mathrm{Ca}_{\mathrm{V}} 1.2$ channel endocytosis in cardiomyocytes. As already discussed, channel removal from the sarcolemma has been visualized in these cells $[54,59]$ but the mechanisms underlying it, and focused study of channel removal/endocytosis from distinct compartments of the membrane such as the $t$-tubules, crest, or caveolae, has not been explored. It is known that the endosomal recycling pathway is replenished by endocytosed channels, as nicely illustrated by the apparent increase in plasma membrane localized $\mathrm{Ca}_{\mathrm{V}} 1.2$, and concominant reduction of the Rab11-positive pool of endosomal Cav1.2 channels when dynamin-dependent endocytosis was pharmacologically inhibited with dynasore in HL-1 cells [71]. Cell surface biotinylation experiments performed on adult ventricular myocytes also suggest that dynasore treatment increases the surface expression of $\mathrm{Ca}_{\mathrm{V}} 1.2$ [72]. However, dynasore is known to have off-target effects and can inhibit both dynamin-dependent and dynamin-independent endocytosis [73]. Like other membrane proteins, endocytosis of $\mathrm{Ca}_{\mathrm{V}} 1.2$ channels, may occur via a dynamin-dependent mechanism which may be further subclassified into either clathrin-dependent or clathrin-independent, or it can occur though dynamin-independent mechanisms [74,75]. In neurons, depolarization and activity dependent endocytosis of $\mathrm{Ca}_{\mathrm{V}} 1.2$ channels has been reported to occur and is thought to impart a level of protection against $\mathrm{Ca}^{2+}$ overload and associated neurotoxicity [76-78]. More in depth investigations are required to determine whether a similar cardioprotective mechanism occurs in cardiac muscle cells and to fully explore the mechanisms of endocytosis in these cells.

\section{5. $C a_{V} 1.2$ Degradation}

Upon endocytosis, $\mathrm{Ca}_{\mathrm{V}} 1.2$ channels enter early endosomes (also known as sorting endosomes) where they are sorted and designated for either recycling or degradation [79]. Sorting signals, which enable recognition that a given cargo should be routed to the degradation pathway, include the presence of covalently attached ubiquitin [80]. Ubiquitination is a post-translational modification that involves addition of small $7 \mathrm{kDa}$ ubiquitin to target proteins in a process that involves a series of enzymes called E1, E2, and E3 [80]. E1 activates ubiquitin in an ATP-dependent manner, and E2 then transfers it to E3-ubiquitin ligases which then covalently attach one or more ubiquitins to a lysine residue on their target protein. Ubiquitination of membrane proteins can stimulate their endocytosis, and/or function as a sorting signal recognized in the early endosome and result in targeting to late endosomes and lysosomes for degradation [81]. Ubiquitination can also occur to newly formed Cav1.2 channels on the ER membrane and when it occurs there, channels are 
targeted to the proteasome for degradation. Figure 2 (top panel) shows an illustration of the endosomal degradation pathway, highlighting the role of Rab7 which regulates movement of vesicular cargo to late endosomes and lysosomes for degradation. Rab11b is also illustrated there in the recycling endosome where, it reportedly plays a role in targeting $\mathrm{Ca}_{\mathrm{V}} 1.2$ channels out of the recycling endosome and toward degradation in mouse neonatal cardiomyocytes [82]. This is in contrast to the role that we and others have reported for its close family member Rab11a in facilitating slow recycling of Cav1.2 in HL-1 cells [71] and adult mouse ventricular myocytes [54].

Nedd4 ubiquitin ligases are expressed in the heart and have been reported to ubiquitinate various cardiac ion channels including $\mathrm{Na}_{\mathrm{V}} 1.5$ and hERG [80]. Nedd4-1 reportedly plays a role in reducing total and surface membrane expression of $\mathrm{Ca}_{V} 1.2 \alpha_{1 \mathrm{c}}$ in transfected tsA-201 cells by promoting channel degradation [83]. Furthermore, co-expression of an adaptor protein called lipopolysaccharide-induced tumor necrosis factor (LITAF) was found to enhance $\alpha_{1 \mathrm{c}}$ ubiquitination levels [84]. In rabbit cardiomyocytes, overexpression of LITAF has been found to decrease $\mathrm{I}_{\mathrm{Ca}}$, reduce $\mathrm{Ca}^{2+}$ transient amplitude, and lower total $\alpha_{1 \mathrm{c}}$ transcriptional expression [84]. An earlier study concluded that Nedd4-1 effects on $\mathrm{Ca}_{\mathrm{V}} 1.2$ were not direct as they could not detect ubiquitination of any of the channel subunits in transfected tsA-201 cells but did observe a significant reduction of $\mathrm{I}_{\mathrm{Ca}}$, and surface biotinylation assays and western blots revealed reduced surface and total cellular channel expression [83]. Brefeldin-A, an inhibitor of ER-Golgi trafficking, abrogated the Nedd4-1 effects suggesting that the enzyme was acting to promote sorting of newly synthesized channels for degradation, even before their forward traffic to the membrane. Furthermore, Nedd4-1 dependent degradation of Cav1.2 was prevented by MG132 an inhibitor of the proteasome, while lysosomal inhibitors also impacted the regulatory effects on $\mathrm{Ca}_{\mathrm{V}} 1.2$, implying that Nedd4-1 promoted channel sorting toward both of these degradation pathways. Interestingly, the Nedd4-1 effects on channel degradation were dependent on co-expression of $\mathrm{Ca}_{\mathrm{v}} \beta$ subunits. Recall that binding of $\mathrm{Ca}_{\mathrm{v}} \beta$ to $\mathrm{Ca}_{\mathrm{v}} \alpha_{1 \mathrm{c}}$ in the $\mathrm{ER}$, is thought to protect neuronal $\mathrm{Ca}_{\mathrm{V}} 1.2$ channels from ubiquitination and proteosomal degradation [52], so the dependence of this Nedd4- 1 effect on $\mathrm{Ca}_{V} \beta$ implies interference with its binding or chaperoning of $\alpha_{1 \mathrm{c}}$. A similar dependence on $\operatorname{Cav}_{\mathrm{V}} \beta$ was also noted in the more recent Moshal et al. study [84].

An elegant study from the Colecraft lab recently capitalized on the importance of $\mathrm{Ca}_{\mathrm{V}} \beta$ subunits for stable membrane expression of $\mathrm{Ca}_{\mathrm{V}} 1.2$ in their report on the creation of a potent engineered $\mathrm{Ca}_{\mathrm{V}} 1.2$ channel inhibitor which targets the catalytic domain of Nedd4-2 E3-ubiquitin ligase to $\mathrm{CaV}_{\mathrm{V}} \beta$ subunits using a nanobody [85]. Adenoviral transduction of adult guinea pig cardiomyocytes with this cleverly named ' $\mathrm{Ca}_{\mathrm{V}}$-aßlator' led to complete eradication of $\mathrm{I}_{\mathrm{Ca}}$, due to removal of $\mathrm{Ca}_{\mathrm{V}} 1.2$ from the dyad and routing to Rab7 positive late endosomes for degradation. Thus, despite the doubt cast on whether $\mathrm{Ca}_{\mathrm{V}} \beta$ plays an essential role in $\mathrm{Ca}_{\mathrm{V}} 1.2$ forward trafficking, it seems to play an important role in regulating its degradation and in this way controlling its membrane availability. Moreover, given that $\mathrm{Ca}_{V}$-a $\beta$ lator was targeted toward the $\mathrm{Ca}_{V} \beta$ subunit, yet ubiquitination was detected on both $\mathrm{Ca}_{\mathrm{V}} \beta$ and $\mathrm{Ca}_{\mathrm{V}} \alpha_{1 \mathrm{c}}$, leading to channel redistribution from the dyad to Rab7 positive late endosomes, this work raises the intriguing question, does $\mathrm{Ca}_{V} \beta$ binding to $\mathrm{Ca}_{\mathrm{V}} \alpha_{1 \mathrm{c}}$ at the sarcolemma confer a protection from ubiquitination in an analogous manner to that described in the ER of neurons [52]? This question remains unanswered.

\section{Cav1.2 Localization and Targeting}

\subsection{Dyads}

To fulfill their function as a channel for $\mathrm{Ca}^{2+}$ flux from the extracellular milieu into the cytosol, $\mathrm{Ca}_{\mathrm{V}} 1.2$ channels need to make their way to the sarcolemma. In the heart, the sarcolemma is a complex system of periodically arranged t-tubules approximately coincident with the $\mathrm{z}$-lines, as well as the region on the surface of the cell between $\mathrm{t}$-tubules known as the surface sarcolemma or crest [86,87]. T-tubules plunge $2-9 \mu \mathrm{m}$ deep into the myocytes [87] and bring the membrane into close $(\sim 12 \mathrm{~nm})$ proximity of junctional 
sarcoplasmic reticulum (jSR) localized ryanodine receptors (RyR2) at sites known as dyads or couplons. At some locations, the surface sarcolemma also comes into close apposition with the jSR and these non-t-tubular couplons are estimated to represent $22-25 \%$ of the total cellular couplon content [88]. Several reports have weighed in on the proportion of total $\mathrm{Ca}_{\mathrm{V}} 1.2$ expressed at dyads with Scriven et al. estimating that $75 \%$ of $\mathrm{Ca}_{V} 1.2$ channel clusters reside at these specialized initiation sites of EC-coupling [89], while Pásek et al. found that approximately $80 \%$ of $\mathrm{Ca}_{\mathrm{V}} 1.2$ is localized to the t-tubule membranes [90]. Dyadic Cav1.2 channels are essential components of cardiac EC-coupling, this is demonstrated during heart failure when the architecture of cardiomyocytes is remodeled, and t-tubules become fractured, displaced, disorganized, and separated from the jSR [72] creating orphaned RYR2 [91], and resulting in reduced $\mathrm{Ca}^{2+}$ transient amplitude, contractile dysfunction, and promotion of arrhythmia promoting dyssynchronous $\mathrm{Ca}^{2+}$ release events [92-95]. $\beta_{2}$-adrenergic receptors ( $\beta_{2}$-ARs) preferentially signal on the t-tubule membrane [96]. In contrast, $\beta_{1}$-adrenergic receptors ( $\beta_{1}$-ARs) are located across the entire sarcolemma and produce less restrictive, global signals [96-98]. Regulation of $\mathrm{Ca}_{V} 1.2$ channels by $\beta$-ARs is the most important regulatory pathway for tuning of cardiac EC-coupling to meet metabolic and hemodynamic demands.

Given the importance of $\mathrm{t}$-tubule localized $\mathrm{Ca}_{V} 1.2$ channels for the fundamental process and tuning of EC-coupling, it is vital that an efficient trafficking route exists to deliver and maintain a functional $\mathrm{Ca}_{\mathrm{V}} 1.2$ channel population at these sites. It has been determined that targeted transport of $\mathrm{Ca}_{V} 1.2$ channels to the $\mathrm{t}$-tubule membrane is conferred by Bridging integrator 1 (BIN1) [72], a member of the membrane-curvature mediating BAR (Bin1-Amphiphysin-Rvs) domain superfamily that is also involved in biogenesis and maintenance of the $t$-tubule network [99-101]. BIN1 has been shown to anchor microtubules at the t-tubule membrane, providing a delivery 'hub' for $\mathrm{Ca}_{\mathrm{V}} 1.2$ channels as they exit the TGN and travel in vesicles along these cellular highways in the anterograde trafficking pathway [72]. A multitude of evidence supports this idea as discussed below. Firstly, immunolabeling of $\mathrm{Ca}_{\mathrm{V}} 1.2$ and BIN1 in ventricular myocytes has revealed the two proteins colocalize along the t-tubules, biochemical studies have indicated they co-IP, while transfection-mediated overexpression of BIN1 in atrial HL-1 and non-cardiac HeLa celllines co-transfected with $\mathrm{Ca}_{\mathrm{V}} 1.2$ results in enhanced formation of membrane invaginations and surface expression of $\mathrm{Ca}_{V} 1.2$ [72]. Lentiviral transduction of human embryonic stem cell-derived cardiomyocytes (hESC-CMs) with BIN1 facilitates development of the t-tubule network and $\mathrm{Ca}_{V} 1.2$ clustering, cooperative gating, and overall activity $\left(\mathrm{P}_{\mathrm{o}}\right)$ [101]. Dynamic imaging of BIN1 and $\alpha$-tubulin in HeLa cells has revealed tethering of microtubules at BIN1-positive sites [72]. In the more architecturally complex adult ventricular myocytes, vesicular $\mathrm{Ca}_{\mathrm{V}} 1.2$ has been shown to decorate cardiomyocyte and microtubules [54,72]. BIN1 knockdown in the heart either with siRNA [72] or shRNA [102], a cardiac specific knockout mouse model [99], or pathologically during heart failure [102], results in reduced Cav1.2 channel expression at the cell surface and t-tubules [102]. Further evidence of a role for microtubules and BIN1 in $\mathrm{Ca}_{V} 1.2$ delivery to the surface is provided by the reported blunting of cell surface accumulation of Cav1.2 in cells where both dynamin-mediated endocytosis and microtubule-dependent delivery were pharmacologically disrupted with dynasore and nocodazole over 18-24 h [72]. This dependence on microtubules for maintenance of surface $\mathrm{Ca}_{\mathrm{V}} 1.2$ channel expression appears absent in the less specialized atrial HL-1 cell-line lacking in t-tubules wherein $18 \mathrm{hr}$ incubation in nocodazole left Cav1.2 channel $I_{\mathrm{Ca}}$ density unaltered [71].

The precise nature of the molecular interaction between BIN1 and microtubules has not yet been fully elucidated but may involve the cytoplasmic linker protein CLIP-170 [103,104]. Localization of phosphorylated CLIP-170 is most evident in the intercalated disks of adult mouse cardiomyocytes [105] but close inspection of the images in the aforementioned article reveals a robust periodic staining pattern that appears to coincide with the z-lines and so conceivable that CLIP-170 could be an intermediate between BIN1 and microtubules in these cells. However, in skeletal muscle this CLIP-170-BIN1 interaction appears to at 
least partially rely on the BAR domain of BIN1, as a point mutation in this region strongly reduced co-IP of BIN1 with CLIP-170 [103]. This is somewhat in conflict with a previous report that truncated BIN1, named BIN1-BAR (as it retains the BAR-domain important for the membrane curvature-mediating effects of BIN1, but lacks the coiled-coil and SRC homology 3 (SH3) domains,) fails to recruit $\mathrm{Ca}_{\mathrm{V}} 1.2$ channels to the surface membrane [72], the inference being that the BAR domain in the cardiac isoforms of BIN1 is neither necessary nor sufficient for the $\mathrm{Ca}_{V} 1.2$ trafficking and targeting effects. It should be noted that these BIN1-BAR experiments were performed in HL-1 cells which, as already discussed above, may have a less robust reliance on microtubules for anterograde trafficking of $\mathrm{Ca}_{\mathrm{V}}$ 1.2. It remains to be seen if BIN1 and CLIP-170 co-localize and co-IP in ventricular myocytes.

BIN1 has been reported to bind to another cytoskeletal highway, actin via its BAR domain [106]. The SH3 domain of BIN1 has further been found to interact with neuronal Wiskott-Aldrich syndrome protein (N-WASP) [107], and there is evidence that the cardiacspecific isoform of BIN1 (lacking exon 7, 11 and 14-16 but containing exons 13 and 17, A.K.A. BIN1 + $13+17$ ), can bind to and activate N-WASP to promote actin polymerization by Arp2/3 complexes $[99,108]$. BIN1 $+13+17$ also associates with F-actin and $\alpha$-actinin, and these interactions likely stabilize $\mathrm{t}$-tubules by anchoring them to the z-lines via $\alpha$ actinin [99]. Indeed, actin stabilization with cytochalasin-D is well-known to preserve the t-tubule network in cultured cardiomyocytes $[109,110]$. Additionally, BIN1 + $13+17$ is thought to be the main cardiac isoform responsible for generating micro-folds on the t-tubule membrane [99]. It has been speculated that these microfolds may limit the lateral diffusion of $\mathrm{Ca}_{\mathrm{V}} 1.2$ channels in the membrane and thus facilitating channel clustering. Indeed, in a conference abstract we have yet to develop into a full manuscript [111], we reported that $\mathrm{Ca}_{\mathrm{V}} 1.2$ channel clusters are $\sim 42 \%$ smaller in cardiac-specific BIN1 heterozygous knockout $\left(\mathrm{BIN1}^{+/-}\right)$mouse ventricular myocytes that have a less dense population of t-tubule micro-folds than WT counterparts [99]. Pharmacological disruption of actin with latrunculin-A reportedly decreases the amount of membrane in ventricular myocyte $\mathrm{t}$-tubules after $24 \mathrm{~h}$ in culture, compared to controls, suggesting that actin organizes and supports the highly folded regions of the t-tubules [99]. This finding appears contrary to a previous report that inhibition of actin polymerization with latrunculin-B enhances membrane tubule formation by F-BAR and BAR-proteins [112]. Two explanations were presented for this enhanced tubulation: firstly, actin disruption removes the stabilizing membrane scaffold and permits enhanced membrane deformation; second, they suggested an indirect antagonistic effect of the disruption of actin on dynamin such that endocytic vesicles that normally bud-off the membrane to internalize proteins and maintain homeostatic membrane protein populations, no longer underwent efficient fission and instead promoted elongation of membrane tubules. This cell biological study was not performed on cardiomyocytes but on more architecturally primitive COS-7 cells and did not specifically test the effect of actin disruption on BIN1-induced membrane tubulation, but focused on other BAR-domain proteins. In our recent work, we found that short-term $(2 \mathrm{~h})$ actin disruption with latrunculin-A did not appreciably change Cav 1.2 clustering, membrane expression, or current density under basal, unstimulated conditions [54].

Another class of cardiac ion channel, Cx43 hemichannels are known to undergo targeted delivery to the specialized cardiomyocyte membrane region of the intercalated disk in a manner that involves actin 'rest-stops' [113]. These are sites of pause for Cx43containing vesicles that may have traveled from the TGN along a microtubule and are then handed-off to actin to form a pool of sub-membrane channels. Mobilized channels are ultimately handed-back to microtubules to be delivered to their final destination. These actin rest-stops may serve as sorting nexuses to redirect microtubule-mediated delivery to specialized sub-domains, and/or as pick-up locations to add accessory proteins, and/or as intracellular reservoirs to store ready-made channels which can be rapidly inserted into the membrane when demand arises. It remains to be determined whether actin rest stops play a role in $\mathrm{Ca}_{\mathrm{V}} 1.2$ channel trafficking in the heart but recent evidence from our group suggests that the mobilization of an internal pool of endosomal channels in 
adult mouse ventricular myocytes is affected by actin disruption pointing to a role for actin in the endosomal recycling pathway [54]. In HL-1 cells, actin disruption reportedly leads to impaired recycling of Cav1.2 channels via the Rab11a pathway from recycling endosomes to the membrane [71]. A noteworthy point to consider when examining the role of actin in cardiomyocytes is that somewhat oddly, cytochalasin-D, a drug that is widely used as a means to disrupt actin polymerization, appears to have a stabilizing effect on actin in these cells, explaining why it preserves cell shape and prevents loss of $\mathrm{t}$-tubules in culture $[109,110]$. Latrunculin-A on the other hand seems to act in the expected manner to disrupt the actin cytoskeleton $[99,109]$. Stabilization of actin with cytochalasin$\mathrm{D}$ reportedly facilitates $\mathrm{Ca}_{\mathrm{V}} 1.2$ trafficking in cultured cardiomyocytes and prevents the peri-nuclear accumulation of the channels seen in cultured cells without cytochalasin-D supplementation [109]. This implies a role for actin in Cav1.2 trafficking through the biosynthetic and anterograde trafficking pathway. However, actin is also known to play a role in stabilizing and guiding microtubules, so it may also be the case that stabilization of actin and preservation of cell shape and architecture, simply facilitates forward trafficking along microtubules [114-116]. Given the preponderance of data supporting the role of microtubules in forward trafficking of Cav1.2, it seems likely that a substantial portion of the cytochalasin-D effect could be explained by this supporting role of actin.

\subsection{Caveolae}

Caveolae represent another specialized sarcolemmal compartment where a subset of Cav1.2 channels are known to reside [117]. It has been estimated that as much as $15 \%$ of sarcolemmal Cav1.2 reside in caveolae [35]. At 50-100 nm in diameter [118], these flask shaped, cholesterol and sphingolipid rich invaginations of the sarcolemma are much smaller than the $\sim 200-300 \mathrm{~nm}$ mean diameter t-tubules [119], the contrast in size between the two can be appreciated on freeze-fracture electron micrographs of rabbit ventricular myocytes [120]. Caveolae decorate the surface and t-tubular sarcolemma of cardiomyocytes although they are notably absent from dyadic regions [120]. This is perhaps a geometric phenomenon as the dyadic cleft is only $\sim 12-15 \mathrm{~nm}$ wide to allow close proximity between the t-tubular Cav1.2 and jSR localized RYR2, thus the physical restrictions of that narrow space intrinsically exclude 50-100 $\mathrm{nm}$ diameter caveolae. The precise role of caveolar Cav1.2 channels in the heart remains unclear with some studies suggesting their involvement in EC-coupling [121], others finding no role in EC-coupling but supporting a role in ET-coupling [35], and others still finding no role in either physiological processes [122]. In terms of channel regulation, $\beta_{2}-\mathrm{AR}$ are known to specifically associate with $\mathrm{Ca} \mathrm{V}_{\mathrm{V}} 1.2$ and Cav-3 in caveolae [117], and intact caveolae are necessary for $\beta_{2}$-AR-mediated regulation of $\mathrm{Ca}_{\mathrm{V}} 1.2$ channels, but not for their regulation by $\beta_{1}$-ARs. How the channels are targeted to these microdomains remains unknown. The fact that caveolae are sub-diffraction limit structures may have hampered their study thus far but the increased resolution afforded by 'super-resolution' light microscopy techniques may help provide answers as to how $\mathrm{Ca}_{V} 1.2$ channels are localized to these specialized domains, and the role they play there.

\section{Cav1.2 Lifetime}

Studies of the lifetime of $\mathrm{Cav}_{\mathrm{V}} 1.2$ channels in the t-tubule sarcolemma and the caveolar compartments would give us information about the dynamics of channel turnover and may reveal differences in delivery and removal mechanisms during health and disease, or circumstances that promote channel insertion or endocytosis. However, there are no reports of $\mathrm{Ca}_{\mathrm{V}} 1.2$ channel lifetime in adult cardiomyocytes, likely due to a lack of live cell fluorescent markers of the channel and the resistance of these cells to chemical transfection methods. Existing measurements of $\mathrm{Ca}_{\mathrm{V}} 1.2$ channel lifetime have all been performed in immortalized cell-lines, and none examine specific sarcolemmal sub-populations of channels. Nonetheless, there are some interesting insights to be gained from studies in heterologous expression systems. Pulse-chase experiments monitoring the percentage of 'pulsed' channels remaining in the membrane fraction up to $10 \mathrm{~h}$ post-chase, performed 
on transiently transfected human embryonic kidney cells (HEK293) expressing the pore forming $\alpha_{1 \mathrm{c}}$ and auxiliary $\beta_{2 \mathrm{a}}$ subunits suggest the channels have a half-life of $\sim 3 \mathrm{~h}$ [19]. A different study in HEK293T cells tracked pulse-chased channels over a $25 \mathrm{~h}$ period after the chase and reported a half-life of $\alpha_{1 \mathrm{c}}$ of $\sim 25 \mathrm{~h}$, after an initial rapid degradation in the first $4 \mathrm{~h}$ post-chase [123]. The difference in these results is likely because the first study was examining the membrane fraction while the second examined total cellular $\mathrm{Ca}_{\mathrm{v}}$ 1.2. Altogether, these results suggest that membrane $\mathrm{Ca}_{V} 1.2$ turns over more rapidly than cellular $\mathrm{Ca}_{\mathrm{v}}$ 1.2. In agreement with that, a more recent study found that while endogenous $I_{\mathrm{Ca}}$ current density in HL-1 cells was maintained at a stable level for $>18 \mathrm{~h}$ despite disruption of microtubule-based channel delivery with nocodazole, internalization of transfected Cav1.2-HA channels labeled with a 10 min pulse of anti-HA DyLight 488, was seen to occur a much faster rate with a time constant of internalization of 7-8 $\min$ [71]. A similar 9-10 min time constant was obtained in tsA201 cells using an approach in which photoactivatable GFP tagged $\mathrm{Ca}_{\mathrm{V}} 1.2$ was photoactivated and its presence at the membrane measured over the subsequent $100 \mathrm{~min}$ [124]. Conrad et al. posited that if the membrane population can remain at a stable expression level for $>18 \mathrm{~h}$ despite ongoing internalization of channels at this rapid rate, then there must also be an ongoing insertion of channels to counterbalance this [71]. They used a clever 'double pulse-chase' protocol to visualize this dynamic insertion of channels wherein initial surface $\mathrm{Ca}_{\mathrm{V}} 1.2-\mathrm{HA}$ were labeled with anti-HA DyLight 488, and 20 min later, a second pulse of anti-HA DyLight 561 revealed robust staining reflecting the presence of channels that were newly inserted during the intervening $20 \mathrm{~min}$. The authors further concluded that surface membrane $\mathrm{Ca}_{\mathrm{V}} 1.2$ channel population in HL-1 cells is constantly and dynamically maintained by endosomal recycling. This endosomal recycling pathway was studied in more detail by our group in live adult mouse ventricular myocytes, where we found that a pool of readily insertable Cav 1.2 form a reservoir of channels, which is replenished by channel internalization, and can be rapidly mobilized to the $\mathrm{t}$-tubule sarcolemma in times of acute stress [54,59].

\section{GPCR Regulation of Cav1.2 Trafficking \\ 6.1. Stimulated Insertion}

The presence of several internal pools of ready-made $\mathrm{Ca}_{\mathrm{V}} 1.2$ channels, invites the thought that perhaps there is some redundancy in these reservoirs under steady-state basal conditions, and that additional channels from the pools could be rapidly mobilized to the sarcolemma to increase channel and current density in times of high demand. Our lab recently reported that activation of $\beta$-ARs with isoproterenol (ISO; $100 \mathrm{nM}$ ) in isolated adult mouse ventricular myocytes, triggers PKA-dependent augmentation of sarcolemmal insertion of $\mathrm{Ca}_{\mathrm{V}} 1.2$ channels $[54,59]$. We visualized this dynamic process using the aforementioned AAV9-Cav $\beta_{2}$-paGFP biosensor approach, and found that the stimulated insertions occurred extremely rapidly, with a $\tau=4.12 \mathrm{~s}$ at physiological temperature [54]. Immunostaining experiments revealed that these inserted channels were mobilized from subsarcolemmal pools of Rab4 positive endosomes and Rab11 positive recycling endosomes (see illustration of the pathway in Figure 3). This manifested as significantly reduced colocalization between these specific endosomal markers and $\mathrm{Ca}_{\mathrm{V}} 1.2$ after ISO, suggesting that the Cav1.2 cargo of these endosomes had been delivered to the sarcolemma. The role of the Rab4-dependent fast recycling pathway, and the Rab11-dependent slow recycling pathway was confirmed by experiments in transiently transfected tsA-201 cells using dominant negative (GDP-locked) and constitutively active (GTP-locked) Rab4 and Rab11 to study the impact on ISO-induced increase in membrane $\mathrm{Ca}_{V} 1.2$ channel expression. Furthermore, super-resolution microscopy of the t-tubule and sarcolemmal crest regions revealed that stimulated channel insertions occurred predominantly at the $\mathrm{t}$-tubule membrane. This has implications for EC-coupling as more channels in the t-tubule dyad regions could enhance EC-coupling. Indeed we found that the larger superclusters of Cav1.2 channels observed in response to ISO promoted enhanced cooperative gating behaviors [59]. This gating behavior is a known property of $\mathrm{Ca}_{\mathrm{V}} 1.2$ channels in which physically interacting channels within 
a cluster can communicate with one another via $\mathrm{Ca}^{2+}$-calmodulin dependent associations between their C-terminal tails [56]. The opening of the highest activity channel in the cluster drives the other attached channels leading to amplification of $\mathrm{Ca}^{2+}$ influx [55]. This raises an interesting point when one considers that ISO-stimulated insertion of channels is a PKA-dependent phenomenon, wherein super-clustering and enhanced sarcolemmal expression of $\mathrm{Ca}_{\mathrm{V}} 1.2$ is prevented by pharmacological inhibition of PKA with PKAi or H-89 [59]. It is unknown whether PKA-phosphorylation of Cav1.2 channels can occur while they are localized on endosomal membranes but there is a PKA-anchoring protein called D-AKAP2, that associates with endosomes in cardiomyocytes and displays an ISOstimulated enhanced colocalization with Rab11 positive endosomes, that could potentially support that [54]. Notably, D-AKAP2 has been shown to regulate transferrin receptor recycling through interactions with Rab4 and Rab11 [125], and a human functional polymorphism in D-AKAP2 (1646V), is known to lower heart rate variability [126], suggestive of a heart that cannot respond well to stressors. PKA-phosphorylation of the $\mathrm{Ca}_{\mathrm{V}} 1.2$ channel complex leads to enhanced open probability $\left(\mathrm{P}_{\mathrm{o}}\right)$ of these channels, and increased longerlived mode 2 openings, that generates enhanced $\mathrm{Ca}^{2+}$ influx and the positive inotropic response downstream of $\beta$-AR activation during the fight-or-flight response [39,127-129]. Thus, it is possible that just a small number of high $\mathrm{P}_{\mathrm{o}}$, phosphorylated channels inserted into the membrane from the endosomal pool could have a disproportionately large effect on $I_{C a}$ and EC-coupling. This idea that $\beta$-AR signaling-mediated regulation of $\mathrm{Ca}_{\mathrm{V}} 1.2$ channel recycling could by itself, generate the stereotypical augmentation of $I_{\mathrm{Ca}}$ seen in cardiomyocytes during flight-or-flight, is supported by functional patch clamp data in which disruption of endosomal channel insertion with cytoskeletal disruptors, abrogates the left-ward shift in voltage-dependent activation and enhanced $I_{\mathrm{Ca}}$ response to ISO despite preserved ISO-stimulated cAMP production and robust adrenergic signaling [54]. The idea that an increase in the number of functional channels in the sarcolemma could at least partially underlie the augmented $I_{\mathrm{Ca}}$ associated with $\beta$-AR signaling was previously suggested by Bean et al. in a 1984 study on frog ventricular heart cells where fluctuation analysis of $I_{\mathrm{Ca}}$ recordings revealed an ISO-stimulated increase in the number of functional channels per cell [130], although the same group later clarified that an increase in the number of functional channels did not necessarily mean there were more channels in the membrane, but could instead reflect previously quiescent channels that became more compelled to open in the presence of ISO [131]. Nonetheless, receptor stimulation of ion channel insertion from intracellular pools has been reported in several other cells and tissues including: (1) neurons where $\beta_{2}$-AR signaling via $G_{\alpha s} /$ adenylyl cyclase/cAMP/PKA stimulates Rab11-dependent insertion of AMPA receptors from recycling endosomes into the plasma membrane of dendritic spines [132]; (2) kidney, where V2R vasopressin receptor signaling through $\mathrm{G}_{\alpha \mathrm{s}}$ /adenylyl cyclase/cAMP/PKA stimulates PKA-dependent insertion of aquaporin 2 (AQP2) from Rab11-positive recycling endosomes into the apical membrane $[133,134]$; and (3) heart, where two other cardiac ion channels, namely $\mathrm{K}_{\mathrm{ATP}}$ and KCNQ1 are mobilized from Rab11-positive endosomal pools to the sarcolemma in response to acute stress [135-137].

\subsection{Stimulated Endocytosis}

The endosomal reservoir of channels, which is constantly replenished by ongoing channel internalization, may similarly have the capacity to accommodate more channels if there is a need to reduce sarcolemmal channel density. This may occur if an analogous $\mathrm{Ca}^{2+}$ overload-preventative channel internalization system as has been described in neurons, also exists in cardiomyocytes [76-78]. Prolonged activation of $\mathrm{AT}_{1} \mathrm{R}$ receptors with angiotensin II has been reported to stimulate endocytosis/internalization of $\mathrm{Ca}_{\mathrm{V}} 1.2$ channels in adult rat cardiomyocytes [138]. This process is seen to occur over about an hour and involves $\beta$-arrestin 1 recruitment to $t$-tubular $\mathrm{Ca}_{V} 1.2$ channels. A preferential internalization of t-tubule localized channels occurs over the period of around an hour and leads to reduced $I_{C a}$ and reduced amplitude $\mathrm{Ca}^{2+}$ transients and cell-shortening. It remains to be determined 
what endosomal pool these channels are targeted toward and whether they can be quickly recycled back to the membrane again after the angiotensin II stimulus is removed, or if they are targeted for degradation. Results from Hermosilla et al. suggest that a subpopulation of the endocytosed channels may be redistributed to surface membrane locations as indicated by enhanced immunostaining of $\mathrm{Ca}_{\mathrm{V}} 1.2$ on the surface membrane while t-tubular signal faded. This stimulated endocytosis pathway is represented in Figure 4.

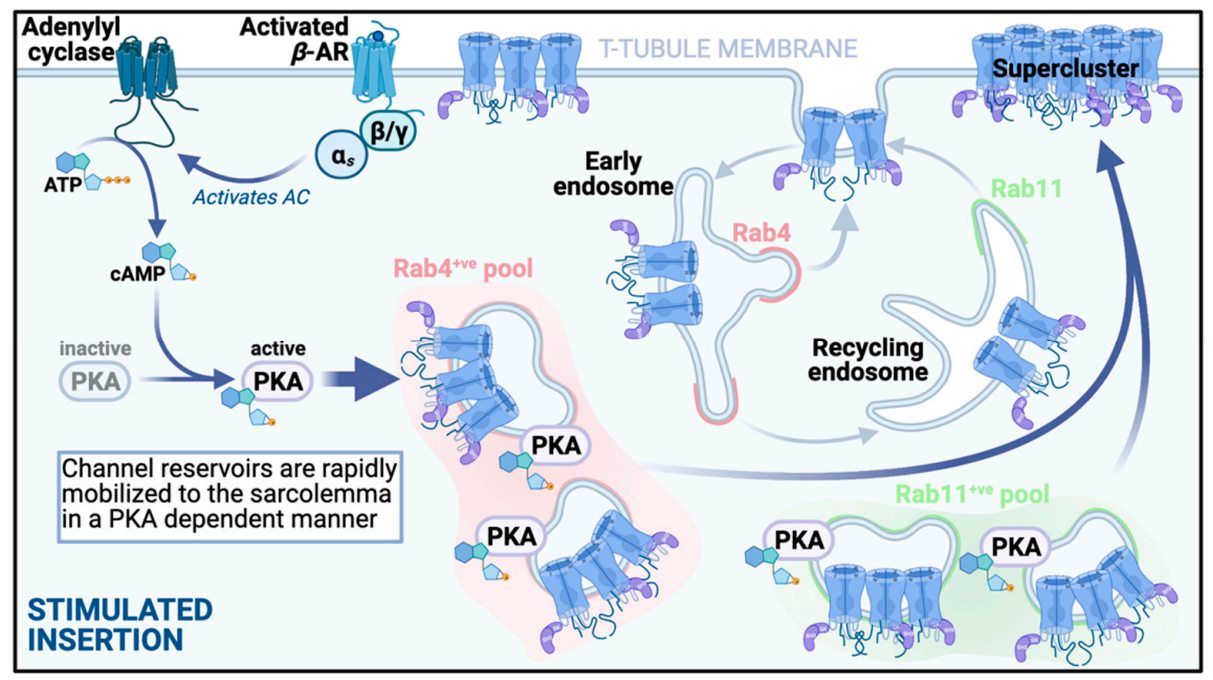

Figure 3. $\beta$-adrenergic receptor stimulated insertion. An illustration of the stimulated insertion pathway that ensues upon acute activation of $\mathrm{G}_{\mathrm{s}}$-coupled $\beta$-ARs. Reservoirs of preformed channels are present in subsarcolemmal pools. Activation of the $\beta$-AR/AC/cAMP/PKA pathway triggers rapid mobilization of these individual and clustered channels to the $t$-tubule membrane, along Rab4 and Rab11 dependent trafficking pathways. As a result of this enhanced insertion, there is an increase in the number of functional channels at the sarcolemmal. Large superclusters of Cav1.2 channels form on the t-tubule membrane. These channels exhibit more cooperative interactions and generate enhanced $\mathrm{Ca}^{2+}$ influx to amplify EC-coupling [59].

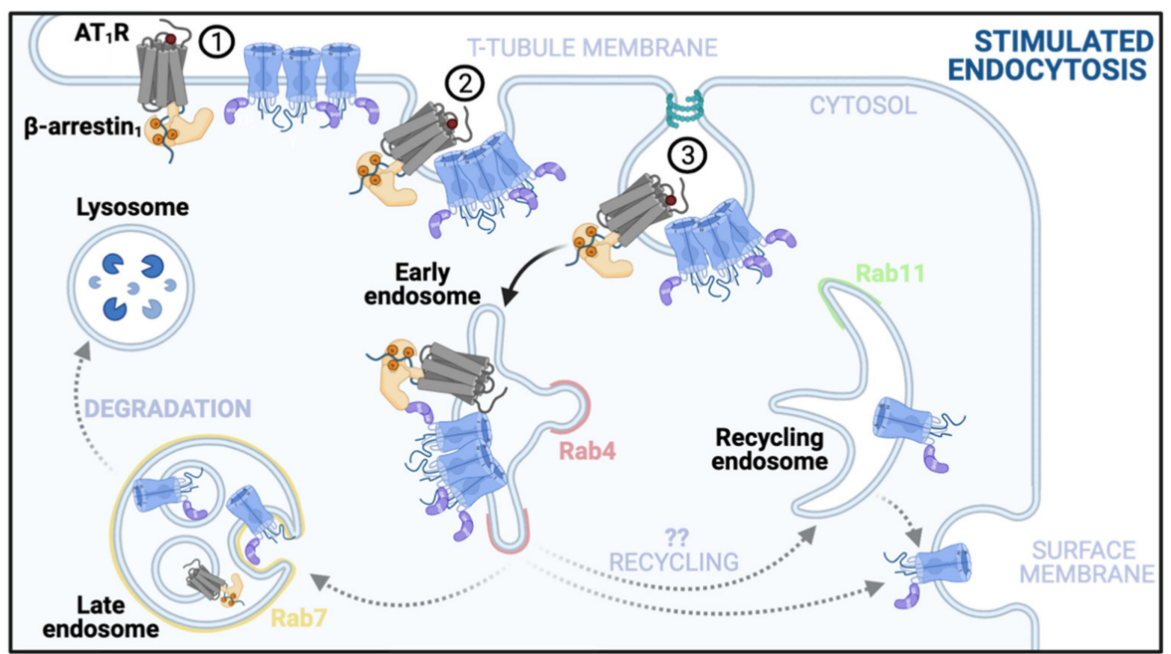

Figure 4. Angiotensin type 1 receptor stimulated endocytosis. Prolonged exposure to angiotensin II, over the course of an hour, leads to: (1) recruitment of $\beta$-arrestin ${ }_{1}$ to t-tubule localized $\mathrm{Ca}_{\mathrm{V}} 1.2$ channel- $\mathrm{AT}_{1} \mathrm{R}$ receptor complexes; (2) clathrincoated pit formation, and (3) endocytosis. This reduces $\mathrm{Ca}_{\mathrm{V}} 1.2$ channel expression and $\mathrm{I}_{\mathrm{Ca}}$. The identity of the cellular compartment to which the channels are targeted upon internalization are unknown as represented by the grey dotted arrows. Their fate may lie in lysosomal degradation or they may be stored in intracellular reservoirs, or finally, as indicated by the study by Altier et al., some channels may be recycled to other membrane regions, including the surface membrane which appeared to grow more intensely positive for $\mathrm{Ca}_{\mathrm{V}} 1.2$ immunostaining as t-tubular and dyadic expression dropped [138]. 
Given the findings that $\beta$-AR stimulation can trigger rapid Cav 1.2 channel insertion into the t-tubule membrane [54,59], an obvious question to explore is whether subsequent phosphatase mediated dephosphorylation of $\mathrm{Ca}_{\mathrm{V}} 1.2$ can trigger internalization. This has been reported to occur in dendritic spines where, as already discussed above, a pool of intracellular GluA1-containing AMPARs is thought to transition to a readily insertable state upon phosphorylation AMPA receptors by PKA and/or calcium/calmodulin-dependent protein kinase II (CaMKII), or protein kinase C (PKC) [139-141]. The resulting plasma membrane insertion of the receptors, facilitates long term potentiation (LTP) by increasing channel open probability $\left(P_{\mathrm{o}}\right)$ and homeostatic scaling up. Conversely, dephosphorylation by calcineurin $(\mathrm{CaN})$ leads to receptor internalization, long term depression and homeostatic scaling down [142]. Whether a similar system exists in cardiomyocytes will make for an interesting future study.

\section{Conclusions}

Cav1.2 channel expression on the cardiomyocyte sarcolemma is tightly controlled and regulated. They are constantly being internalized, sorted, recycled, degraded, but at steadystate this complex system reaches an equilibrium where a constant level of expression is maintained. Regulatory mechanisms have emerged in recent years that suggest the balance between channel insertion and internalization can be tilted by GPCR-mediated regulatory pathways. Rapid channel insertion from endosomal pools provides extra $\mathrm{Ca}_{V} 1.2$ channels to the $\mathrm{t}$-tubule membrane during fight-or-flight to fuel the harder-working myocytes with more $\mathrm{Ca}^{2+}$ influx capacity to generate a positive inotropic effect and meet the enhanced hemodynamic and metabolic demands associated with this response. Furthermore, prolonged $\mathrm{AT}_{1} \mathrm{R}$ signaling triggers channel endocytosis and reduced expression generating a negative inotropic effect. We await further detailed characterization of the kinetics of $\mathrm{Ca}_{\mathrm{V}} 1.2$ channel trafficking, and of when in the anterograde pathway the auxiliary subunits join the complex. Moreover, the specific mechanism of targeting and transport of these channels to non-ttubular locations including caveolae and the surface membrane remains to be determined. An interesting avenue for future research in those topics is that of the role of the junctional tethering protein junctophilin 2 (JPH2) in targeting Cav1.2 to microdomains within the sarcolemma. A recent study reported that JPH2 recruits $\mathrm{Ca}_{V} 1.2$ to lipid rafts on the T-tubules wherein overexpression of JPH2 in cultured rat cardiomyocytes led to increased channel density at the t-tubule and surface membrane that was not accompanied by an increase in total cellular $\mathrm{Ca}_{V} 1.2$ protein, implying JPH2 increased channel trafficking rather than altered channel biosynthesis [143]. Future studies should also parse out the mechanistic details of trafficking alterations that may explain how failing hearts redistribute $\mathrm{Ca}_{\mathrm{V}} 1.2$ from the t-tubular sarcolemma to the surface membrane [144-146], and others that mediate the enhanced $\mathrm{Ca}_{\mathrm{V}} 1.2$ sarcolemmal expression observed with aging [147-149].

It will be important for the field moving forward to have a definitive measure of Cav1.2 channel lifetime in cardiomyocytes and a full picture of how channels are targeted to caveolae, t-tubules, or the surface sarcolemma, and indeed how these targeting mechanisms become altered in disease. The recently developed Retention Using Selective Hooks (RUSH) system [150] may make more accurate measurements and visualization of $\mathrm{Ca}_{\mathrm{V}} 1.2$ channel trafficking feasible. This system allows the user to trap channels at certain points along the biosynthetic or recycling pathways, release them at will, and observe the kinetics and direction of the trafficking of the channels as they travel to their destinations in the cell. The RUSH system utilizes various protein 'hooks' fused to streptavidin which reversibly anchor and retain streptavidin-binding peptide (SBP) fused proteins of interest in a cellular compartment. The addition of biotin outcompetes the SBP/streptavidin interaction and severs the connection between the hook and bait allowing the protein to be released into the secretory pathway. This system has recently been used to study glutamate receptor [151], KCNQ1/KCNE1 [152], and to study altered transport kinetics during pathological conditions [153]. One could envisage that this system could be used 
to determine when and where the various auxiliary subunits of the channel join the $\alpha 1$ subunit.

In addition, future studies should examine size and mobility of the endosomal pool of channels and how it may be altered by aging or disease. Furthermore, as already mentioned above, we eagerly anticipate future determination of the molecular mechanisms underlying PKA-triggered mobilization of the endosomal channel reservoirs and whether the inverse effect is seen with phosphatase-mediated channel dephosphorylation. In addition, the question still remains open as to whether the triggered insertion of $\mathrm{Cav}_{\mathrm{V}} 1.2$ channels downstream of $\beta$-adrenergic receptor stimulation, is accompanied by an increase in RyR2 expression on the other side of the dyad. There is some evidence that this might be the case as cardiomyocyte stimulation with isoproterenol reportedly enhances phosphorylated RyR2 clustering in dyadic regions [154]. A coordinated stimulated enhancement of both $\mathrm{Ca}_{\mathrm{V}} 1.2$ and RyR2 in dyadic regions during fight-or-flight could facilitate an even larger inotropic response.

This relationship between $\mathrm{Ca}_{\mathrm{V}} 1.2$ and RyR2 expression raises a final intriguing idea that should be explored. Recent work has suggested that the functional expression of ion channel complexes at the cardiomyocyte sarcolemma is regulated by a 'microtranslatome' whereby mRNA transcripts of $\mathrm{Na}_{\mathrm{V}} 1.5$ and hERG associate with each other during translation to coordinate and regulate the balance of expression of these channels [155]. A fine balance between the depolarizing $\mathrm{Na}_{V} 1.5$ and repolarizing $\mathrm{hERG}$ channels is critical to maintain action potential production of the correct duration and to avoid arrhythmias. The idea of co-translational regulation of $\mathrm{Ca}_{V} 1.2$ is an interesting one considering that gain-of-function mutations in Cav1.2 can lead to long QT8 (Timothy syndrome) [5] and that aberrant interactions between adjacent $\mathrm{Ca}_{V} 1.2$ channels can also facilitate arrhythmogenic activity [56,156,157]. Could there be association between $\mathrm{Ca}_{\mathrm{V}} 1.2$ channel transcripts that regulates its functional expression or balances it against a repolarizing channel? Could $\mathrm{Ca}_{\mathrm{V}} 1.2$ channel subunit transcripts associate and undergo co-translation that facilitates ER export? These are all open questions in this still developing field of $\mathrm{Ca}_{\mathrm{V}} 1.2$ trafficking regulation.

Author Contributions: Conceptualization, R.E.D.; writing-original draft preparation, R.E.D. and M.W.; writing-review and editing, R.E.D. and M.W. All authors have read and agreed to the published version of the manuscript.

Funding: Research in the Dixon lab is supported by NIH NIA grant R01AG063796 to R.E.D.

Acknowledgments: All figures for this manuscript were created with BioRender.com (accessed on 30 May 2021).

Conflicts of Interest: The authors declare no conflict of interest.

\section{References}

1. Zamponi, G.W.; Striessnig, J.; Koschak, A.; Dolphin, A.C. The Physiology, Pathology, and Pharmacology of Voltage-Gated Calcium Channels and Their Future Therapeutic Potential. Pharmacol. Rev. 2015, 67, 821-870. [CrossRef] [PubMed]

2. Catterall, W.A. Voltage-gated calcium channels. Cold Spring Harb. Perspect. Biol. 2011, 3, a003947. [CrossRef] [PubMed]

3. Catterall, W.A.; Lenaeus, M.J.; Gamal El-Din, T.M. Structure and Pharmacology of Voltage-Gated Sodium and Calcium Channels. Annu. Rev. Pharmacol. Toxicol. 2020, 60, 133-154. [CrossRef] [PubMed]

4. Ertel, E.A.; Campbell, K.P.; Harpold, M.M.; Hofmann, F.; Mori, Y.; Perez-Reyes, E.; Schwartz, A.; Snutch, T.P.; Tanabe, T.; Birnbaumer, L.; et al. Nomenclature of Voltage-Gated Calcium Channels. Neuron 2000, 25, 533-535. [CrossRef]

5. Splawski, I.; Timothy, K.W.; Sharpe, L.M.; Decher, N.; Kumar, P.; Bloise, R.; Napolitano, C.; Schwartz, P.J.; Joseph, R.M.; Condouris, K.; et al. Cav1.2 Calcium Channel Dysfunction Causes a Multisystem Disorder Including Arrhythmia and Autism. Cell 2004, 119, 19-31. [CrossRef] [PubMed]

6. Seisenberger, C.; Specht, V.; Welling, A.; Platzer, J.; Pfeifer, A.; Kuhbandner, S.; Striessnig, J.; Klugbauer, N.; Feil, R.; Hofmann, F. Functional embryonic cardiomyocytes after disruption of the L-type $\alpha_{1 \mathrm{C}}\left(\mathrm{Ca}_{\mathrm{V}} 1.2\right)$ calcium channel gene in the mouse. J. Biol. Chem. 2000, 275, 39193-39199. [CrossRef] [PubMed]

7. Gao, T.; Chien, A.J.; Hosey, M.M. Complexes of the $\alpha_{1 \mathrm{C}}$ and $\beta$ Subunits Generate the Necessary Signal for Membrane Targeting of Class C L-type Calcium Channels. J. Biol. Chem. 1999, 274, 2137-2144. [CrossRef]

8. Pérez-García, M.T.; Kamp, T.J.; Marbán, E. Functional properties of cardiac L-type calcium channels transiently expressed in HEK293 cells. Roles of $\alpha_{1}$ and $\beta$ subunits. J. Gen. Physiol. 1995, 105, 289-305. [CrossRef] 
9. Hullin, R.; Khan, I.F.; Wirtz, S.; Mohacsi, P.; Varadi, G.; Schwartz, A.; Herzig, S. Cardiac L-type calcium channel beta-subunits expressed in human heart have differential effects on single channel characteristics. J. Biol. Chem. 2003, 278, 21623-21630. [CrossRef]

10. Savalli, N.; Pantazis, A.; Sigg, D.; Weiss, J.N.; Neely, A.; Olcese, R. The $\alpha 2 \delta-1$ subunit remodels Cav 1.2 voltage sensors and allows $\mathrm{Ca}^{2+}$ influx at physiological membrane potentials. J. Gen. Physiol. 2016, 148, 147-159. [CrossRef]

11. Gurnett, C.A.; Felix, R.; Campbell, K.P. Extracellular Interaction of the Voltage-dependent Ca ${ }^{2+}$ Channel $\alpha_{2} \delta$ and $\alpha_{1}$ Subunits. J. Biol. Chem. 1997, 272, 18508-18512. [CrossRef] [PubMed]

12. Walsh, C.P.; Davies, A.; Butcher, A.J.; Dolphin, A.C.; Kitmitto, A. Three-dimensional Structure of Cav3.1: Comparison with the cardiac L-type voltage-gated calcium channel monomer architecture. J. Biol. Chem. 2009, 284, 22310-22321. [CrossRef]

13. Walsh, C.P.; Davies, A.; Nieto-Rostro, M.; Dolphin, A.C.; Kitmitto, A. Labelling of the 3D structure of the cardiac L-type voltage-gated calcium channel. Channels 2009, 3, 387-392. [CrossRef]

14. De Waard, M.; Pragnell, M.; Campbell, K.P. Ca ${ }^{2+}$ channel regulation by a conserved beta subunit domain. Neuron 1994, 13 , 495-503. [CrossRef]

15. Opatowsky, Y.; Chomsky-Hecht, O.; Kang, M.G.; Campbell, K.P.; Hirsch, J.A. The voltage-dependent calcium channel $\beta$ subunit contains two stable interacting domains. J. Biol. Chem. 2003, 278, 52323-52332. [CrossRef] [PubMed]

16. Chen, Y.-h.; Li, M.-h.; Zhang, Y.; He, L.-1.; Yamada, Y.; Fitzmaurice, A.; Shen, Y.; Zhang, H.; Tong, L.; Yang, J. Structural basis of the $\alpha_{1}-\beta$ subunit interaction of voltage-gated $\mathrm{Ca}^{2+}$ channels. Nature 2004, 429, 675-680. [CrossRef]

17. Richards, M.W.; Leroy, J.; Pratt, W.S.; Dolphin, A.C. The HOOK-Domain Between the SH3- and the GK-Domains of Cav $\beta$ Subunits Contains Key Determinants Controlling Calcium Channel Inactivation. Channels 2007, 1, 92-101. [CrossRef] [PubMed]

18. Weissgerber, P.; Held, B.; Bloch, W.; Kaestner, L.; Chien, K.R.; Fleischmann, B.K.; Lipp, P.; Flockerzi, V.; Freichel, M. Reduced Cardiac L-Type $\mathrm{Ca}^{2+}$ Current in $\mathrm{Ca}_{\mathrm{V}} \beta_{2}{ }^{-/}$Embryos Impairs Cardiac Development and Contraction with Secondary Defects in Vascular Maturation. Circ. Res. 2006, 99, 749-757. [CrossRef] [PubMed]

19. Chien, A.J.; Zhao, X.; Shirokov, R.E.; Puri, T.S.; Chang, C.F.; Sun, D.; Rios, E.; Hosey, M.M. Roles of a membrane-localized $\beta$ subunit in the formation and targeting of functional L-type $\mathrm{Ca}^{2+}$ channels. J. Biol. Chem. 1995, 270, 30036-30044. [CrossRef] [PubMed]

20. Brice, N.L.; Berrow, N.S.; Campbell, V.; Page, K.M.; Brickley, K.; Tedder, I.; Dolphin, A.C. Importance of the different $\beta$ subunits in the membrane expression of the $\alpha_{1 \mathrm{~A}}$ and $\alpha_{2}$ calcium channel subunits: Studies using a depolarization-sensitive $\alpha_{1 \mathrm{~A}}$ antibody. Eur. J. Neurosci. 1997, 9, 749-759. [CrossRef]

21. Gerster, U.; Neuhuber, B.; Groschner, K.; Striessnig, J.; Flucher, B.E. Current modulation and membrane targeting of the calcium channel $\alpha_{1 C}$ subunit are independent functions of the $\beta$ subunit. J. Physiol. 1999, 517, 353-368. [CrossRef]

22. Wei, S.-k.; Colecraft, H.M.; DeMaria, C.D.; Peterson, B.Z.; Zhang, R.; Kohout, T.A.; Rogers, T.B.; Yue, D.T. Ca ${ }^{2+}$ Channel Modulation by Recombinant Auxiliary $\beta$ Subunits Expressed in Young Adult Heart Cells. Circ. Res. 2000, 86, 175-184. [CrossRef]

23. Fang, K.; Colecraft, H.M. Mechanism of auxiliary $\beta$-subunit-mediated membrane targeting of L-type (Ca 1.2$)$ channels. J. Physiol. 2011, 589, 4437-4455. [CrossRef] [PubMed]

24. Dalton, S.; Takahashi, S.X.; Miriyala, J.; Colecraft, H.M. A single $\mathrm{Ca}_{\mathrm{V}} \beta$ can reconstitute both trafficking and macroscopic conductance of voltage-dependent calcium channels. J. Physiol. 2005, 567, 757-769. [CrossRef]

25. Gao, T.; Bünemann, M.; Gerhardstein, B.L.; Ma, H.; Hosey, M.M. Role of the C terminus of the $\alpha_{1 C}\left(C_{V} 1.2\right)$ Subunit in Membrane Targeting of Cardiac L-type Calcium Channels*. J. Biol. Chem. 2000, 275, 25436-25444. [CrossRef] [PubMed]

26. Davies, A.; Kadurin, I.; Alvarez-Laviada, A.; Douglas, L.; Nieto-Rostro, M.; Bauer, C.S.; Pratt, W.S.; Dolphin, A.C. The $\alpha_{2} \delta$ subunits of voltage-gated calcium channels form GPI-anchored proteins, a posttranslational modification essential for function. Proc. Natl. Acad. Sci. USA 2010, 107, 1654-1659. [CrossRef]

27. Klugbauer, N.; Lacinová, L.; Marais, E.; Hobom, M.; Hofmann, F. Molecular Diversity of the Calcium Channel $\alpha_{2} \delta$ Subunit. J. Neurosci. 1999, 19, 684-691. [CrossRef] [PubMed]

28. Angelotti, T.; Hofmann, F. Tissue-specific expression of splice variants of the mouse voltage-gated calcium channel $\alpha_{2} \delta$ subunit. FEBS Lett. 1996, 397, 331-337. [CrossRef]

29. Cantí, C.; Nieto-Rostro, M.; Foucault, I.; Heblich, F.; Wratten, J.; Richards, M.W.; Hendrich, J.; Douglas, L.; Page, K.M.; Davies, A.; et al. The metal-ion-dependent adhesion site in the Von Willebrand factor-A domain of $\alpha_{2} \delta$ subunits is key to trafficking voltage-gated $\mathrm{Ca}^{2+}$ channels. Proc. Natl. Acad. Sci. USA 2005, 102, 11230-11235. [CrossRef]

30. Yang, L.; Katchman, A.; Morrow, J.P.; Doshi, D.; Marx, S.O. Cardiac L-type calcium channel (Ca 1 1.2) associates with gamma subunits. FASEB J. 2011, 25, 928-936. [CrossRef]

31. Green, W.N. Ion channel assembly: Creating structures that function. J. Gen. Physiol. 1999, 113, 163-170. [CrossRef]

32. Blobel, G.; Sabatini, D. Dissociation of mammalian polyribosomes into subunits by puromycin. Proc. Natl. Acad. Sci. USA 1971, 68, 390-394. [CrossRef]

33. Gorlich, D.; Rapoport, T.A. Protein translocation into proteoliposomes reconstituted from purified components of the endoplasmic reticulum membrane. Cell 1993, 75, 615-630. [CrossRef]

34. Fabiato, A. Simulated calcium current can both cause calcium loading in and trigger calcium release from the sarcoplasmic reticulum of a skinned canine cardiac Purkinje cell. J. Gen. Physiol. 1985, 85, 291-320. [CrossRef] 
35. Makarewich, C.A.; Correll, R.N.; Gao, H.; Zhang, H.Y.; Yang, B.H.; Berretta, R.M.; Rizzo, V.; Molkentin, J.D.; Houser, S.R. A Caveolae-Targeted L-Type $\mathrm{Ca}^{2+}$ Channel Antagonist Inhibits Hypertrophic Signaling Without Reducing Cardiac Contractility. Circ. Res. 2012, 110, 669-674. [CrossRef]

36. Buraei, Z.; Yang, J. Structure and function of the beta subunit of voltage-gated $\mathrm{Ca}^{2+}$ channels. Biochim. Biophys. Acta 2013, 1828, 1530-1540. [CrossRef]

37. Buraei, Z.; Yang, J. The ss subunit of voltage-gated Ca ${ }^{2+}$ channels. Physiol. Rev. 2010, 90, 1461-1506. [CrossRef] [PubMed]

38. Papa, A.; Kushner, J.; Hennessey, J.A.; Katchman, A.N.; Zakharov, S.I.; Chen, B.X.; Yang, L.; Lu, R.; Leong, S.; Diaz, J.; et al. Adrenergic Ca 1.2 Activation via Rad Phosphorylation Converges at $\alpha_{1 C}$ I-II Loop. Circ. Res. 2021, 128, 76-88. [CrossRef] [PubMed]

39. Liu, G.; Papa, A.; Katchman, A.N.; Zakharov, S.I.; Roybal, D.; Hennessey, J.A.; Kushner, J.; Yang, L.; Chen, B.X.; Kushnir, A.; et al. Mechanism of adrenergic Cav1.2 stimulation revealed by proximity proteomics. Nature 2020, 577, 695-700. [CrossRef] [PubMed]

40. Obermair, G.J.; Schlick, B.; Di Biase, V.; Subramanyam, P.; Gebhart, M.; Baumgartner, S.; Flucher, B.E. Reciprocal interactions regulate targeting of calcium channel $\beta$ subunits and membrane expression of $\alpha_{1}$ subunits in cultured hippocampal neurons. J. Biol. Chem. 2010, 285, 5776-5791. [CrossRef]

41. Dolphin, A.C. $\beta$ subunits of voltage-gated calcium channels. J. Bioenerg. Biomembr. 2003, 35, 599-620. [CrossRef]

42. Kanevsky, N.; Dascal, N. Regulation of maximal open probability is a separable function of $\mathrm{Ca}_{\mathrm{V}} \beta$ subunit in L-type Ca ${ }^{2+}$ channel, dependent on NH2 terminus of $\alpha_{1 C}\left(\mathrm{Ca}_{\mathrm{V}} 1.2 \alpha\right)$. J. Gen. Physiol. 2006, 128, 15-36. [CrossRef] [PubMed]

43. Josephson, I.R.; Varadi, G. The beta subunit increases $\mathrm{Ca}^{2+}$ currents and gating charge movements of human cardiac L-type Ca ${ }^{2+}$ channels. Biophys. J. 1996, 70, 1285-1293. [CrossRef]

44. Yang, L.; Katchman, A.; Kushner, J.S.; Kushnir, A.; Zakharov, S.I.; Chen, B.X.; Shuja, Z.; Subramanyam, P.; Liu, G.; Papa, A.; et al. Cardiac $\mathrm{Ca}_{\mathrm{V}} 1.2$ channels require beta subunits for beta-adrenergic-mediated modulation but not trafficking. J. Clin. Investig. 2018. [CrossRef]

45. Mori, Y.; Friedrich, T.; Kim, M.S.; Mikami, A.; Nakai, J.; Ruth, P.; Bosse, E.; Hofmann, F.; Flockerzi, V.; Furuichi, T.; et al. Primary structure and functional expression from complementary DNA of a brain calcium channel. Nature 1991, 350, 398-402. [CrossRef] [PubMed]

46. Kamp, T.J.; Perez-Garcia, M.T.; Marban, E. Enhancement of ionic current and charge movement by coexpression of calcium channel beta 1A subunit with $\alpha_{1 C}$ subunit in a human embryonic kidney cell line. J. Physiol. 1996, 492, 89-96. [CrossRef]

47. Yamaguchi, H.; Okuda, M.; Mikala, G.; Fukasawa, K.; Varadi, G. Cloning of the $\beta_{2 a}$ subunit of the voltage-dependent calcium channel from human heart: Cooperative effect of $\alpha_{2} \delta$ and $\beta_{2 a}$ on the membrane expression of the $\alpha_{1 C}$ subunit. Biochem. Biophys. Res. Commun. 2000, 267, 156-163. [CrossRef]

48. Pragnell, M.; De Waard, M.; Mori, Y.; Tanabe, T.; Snutch, T.P.; Campbell, K.P. Calcium channel $\beta$-subunit binds to a conserved motif in the I-II cytoplasmic linker of the alpha 1-subunit. Nature 1994, 368, 67-70. [CrossRef]

49. He, L.L.; Zhang, Y.; Chen, Y.H.; Yamada, Y.; Yang, J. Functional modularity of the $\beta$-subunit of voltage-gated Ca ${ }^{2+}$ channels Biophys. J. 2007, 93, 834-845. [CrossRef] [PubMed]

50. Van Petegem, F.; Duderstadt, K.E.; Clark, K.A.; Wang, M.; Minor, D.L., Jr. Alanine-scanning mutagenesis defines a conserved energetic hotspot in the $\mathrm{Ca}_{V} \alpha_{1}$ AID-CaV $\beta$ interaction site that is critical for channel modulation. Structure 2008, 16, 280-294. [CrossRef] [PubMed]

51. Bichet, D.; Cornet, V.; Geib, S.; Carlier, E.; Volsen, S.; Hoshi, T.; Mori, Y.; De Waard, M. The I-II loop of the Ca ${ }^{2+}$ channel alpha1 subunit contains an endoplasmic reticulum retention signal antagonized by the beta subunit. Neuron 2000, 25, 177-190. [CrossRef]

52. Altier, C.; Garcia-Caballero, A.; Simms, B.; You, H.; Chen, L.; Walcher, J.; Tedford, H.W.; Hermosilla, T.; Zamponi, G.W. The $\mathrm{Ca}_{\mathrm{V}} \beta$ subunit prevents RFP2-mediated ubiquitination and proteasomal degradation of L-type channels. Nat. Neurosci. 2011, 14, 173-180. [CrossRef] [PubMed]

53. Cingolani, E.; Ramirez Correa, G.A.; Kizana, E.; Murata, M.; Cho, H.C.; Marban, E. Gene therapy to inhibit the calcium channel beta subunit: Physiological consequences and pathophysiological effects in models of cardiac hypertrophy. Circ. Res. 2007, 101, 166-175. [CrossRef] [PubMed]

54. Del Villar, S.G.; Voelker, T.L.; Westhoff, M.; Reddy, G.R.; Spooner, H.C.; Navedo, M.F.; Dickson, E.J.; Dixon, R.E. $\beta$-Adrenergic control of sarcolemmal Cav1.2 abundance by small GTPase Rab proteins. Proc. Natl. Acad. Sci. USA 2021, 118. [CrossRef] [PubMed]

55. Dixon, R.E.; Yuan, C.; Cheng, E.P.; Navedo, M.F.; Santana, L.F. Ca ${ }^{2+}$ signaling amplification by oligomerization of L-type Cav1.2 channels. Proc. Natl. Acad. Sci. USA 2012, 109, 1749-1754. [CrossRef] [PubMed]

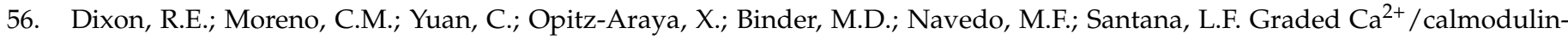
dependent coupling of voltage-gated Cav1.2 channels. eLife 2015, 4, e05608. [CrossRef] [PubMed]

57. Moreno, C.M.; Dixon, R.E.; Tajada, S.; Yuan, C.; Opitz-Araya, X.; Binder, M.D.; Santana, L.F. Ca ${ }^{2+}$ entry into neurons is facilitated by cooperative gating of clustered Cav1.3 channels. eLife 2016, 5. [CrossRef]

58. Ghosh, D.; Nieves-Cintron, M.; Tajada, S.; Brust-Mascher, I.; Horne, M.C.; Hell, J.W.; Dixon, R.E.; Santana, L.F.; Navedo, M.F. Dynamic L-type Cav1.2 channel trafficking facilitates Cav1.2 clustering and cooperative gating. Biochim. Biophys. Acta 2018, 1865, 1341-1355. [CrossRef] 
59. Ito, D.W.; Hannigan, K.I.; Ghosh, D.; Xu, B.; Del Villar, S.G.; Xiang, Y.K.; Dickson, E.J.; Navedo, M.F.; Dixon, R.E. beta-adrenergicmediated dynamic augmentation of sarcolemmal $\mathrm{Ca}_{\mathrm{V}} 1.2$ clustering and co-operativity in ventricular myocytes. J. Physiol. 2019, 597, 2139-2162. [CrossRef]

60. Navedo, M.F.; Amberg, G.C.; Votaw, V.S.; Santana, L.F. Constitutively active L-type Ca ${ }^{2+}$ channels. Proc. Natl. Acad. Sci. USA 2005, 102, 11112-11117. [CrossRef]

61. Navedo, M.F.; Amberg, G.C.; Nieves, M.; Molkentin, J.D.; Santana, L.F. Mechanisms Underlying Heterogeneous Ca ${ }^{2+}$ Sparklet Activity in Arterial Smooth Muscle. J. Gen. Physiol. 2006, 127, 611-622. [CrossRef]

62. Navedo, M.F.; Cheng, E.P.; Yuan, C.; Votaw, S.; Molkentin, J.D.; Scott, J.D.; Santana, L.F. Increased coupled gating of L-type Ca ${ }^{2+}$ channels during hypertension and Timothy syndrome. Circ. Res. 2010, 106, 748-756. [CrossRef]

63. Santana, L.F.; Navedo, M.F. Natural inequalities: Why some L-type Ca ${ }^{2+}$ channels work harder than others. J. Gen. Physiol. 2010, 136, 143-147. [CrossRef] [PubMed]

64. Hymel, L.; Striessnig, J.; Glossmann, H.; Schindler, H. Purified skeletal muscle 1,4-dihydropyridine receptor forms phosphorylationdependent oligomeric calcium channels in planar bilayers. Proc. Nat. Acad. Sci. USA 1988, 85, 4290-4294. [CrossRef] [PubMed]

65. Stenmark, H. Rab GTPases as coordinators of vesicle traffic. Nat. Rev. Mol. Cell Biol. 2009, 10, 513-525. [CrossRef]

66. Jordens, I.; Marsman, M.; Kuijl, C.; Neefjes, J. Rab proteins, connecting transport and vesicle fusion. Traffic 2005, 6, 1070-1077. [CrossRef] [PubMed]

67. Imamura, T.; Huang, J.; Usui, I.; Satoh, H.; Bever, J.; Olefsky, J.M. Insulin-induced GLUT4 translocation involves protein kinase C-lambda-mediated functional coupling between Rab4 and the motor protein kinesin. Mol. Cell. Biol. 2003, 23, 4892-4900. [CrossRef]

68. Maxfield, F.R.; McGraw, T.E. Endocytic recycling. Nat. Rev. Mol. Cell Biol. 2004, 5, 121-132. [CrossRef]

69. Hopkins, C.R.; Trowbridge, I.S. Internalization and processing of transferrin and the transferrin receptor in human carcinoma A431 cells. J. Cell Biol. 1983, 97, 508-521. [CrossRef]

70. Lapierre, L.A.; Kumar, R.; Hales, C.M.; Navarre, J.; Bhartur, S.G.; Burnette, J.O.; Provance, D.W., Jr.; Mercer, J.A.; Bahler, M.; Goldenring, J.R. Myosin vb is associated with plasma membrane recycling systems. Mol. Biol. Cell 2001, 12, 1843-1857. [CrossRef]

71. Conrad, R.; Stölting, G.; Hendriks, J.; Ruello, G.; Kortzak, D.; Jordan, N.; Gensch, T.; Hidalgo, P. Rapid Turnover of the Cardiac L-Type Ca $\mathrm{V}_{\mathrm{V}}$ 1.2 Channel by Endocytic Recycling Regulates Its Cell Surface Availability. iScience 2018, 7, 1-15. [CrossRef]

72. Hong, T.T.; Smyth, J.W.; Gao, D.; Chu, K.Y.; Vogan, J.M.; Fong, T.S.; Jensen, B.C.; Colecraft, H.M.; Shaw, R.M. BIN1 localizes the L-type calcium channel to cardiac T-tubules. PLoS Biol. 2010, 8, e1000312. [CrossRef]

73. Park, R.J.; Shen, H.; Liu, L.; Liu, X.; Ferguson, S.M.; De Camilli, P. Dynamin triple knockout cells reveal off target effects of commonly used dynamin inhibitors. J. Cell Sci. 2013, 126, 5305-5312. [CrossRef] [PubMed]

74. Balse, E.; Steele, D.F.; Abriel, H.; Coulombe, A.; Fedida, D.; Hatem, S.N. Dynamic of ion channel expression at the plasma membrane of cardiomyocytes. Physiol. Rev. 2012, 92, 1317-1358. [CrossRef] [PubMed]

75. Hilgemann, D.W.; Lin, M.J.; Fine, M.; Deisl, C. On the existence of endocytosis driven by membrane phase separations. Biochim. Biophys. Acta Biomembr. 2020, 1862, 183007. [CrossRef]

76. Green, E.M.; Barrett, C.F.; Bultynck, G.; Shamah, S.M.; Dolmetsch, R.E. The tumor suppressor eIF3e mediates calcium-dependent internalization of the L-type calcium channel Cav1.2. Neuron 2007, 55, 615-632. [CrossRef] [PubMed]

77. Hall, D.D.; Dai, S.; Tseng, P.Y.; Malik, Z.; Nguyen, M.; Matt, L.; Schnizler, K.; Shephard, A.; Mohapatra, D.P.; Tsuruta, F.; et al Competition between alpha-actinin and $\mathrm{Ca}^{2+}$-calmodulin controls surface retention of the L-type Ca ${ }^{2+}$ channel Cav1.2. Neuron 2013, 78, 483-497. [CrossRef]

78. Tseng, P.Y.; Henderson, P.B.; Hergarden, A.C.; Patriarchi, T.; Coleman, A.M.; Lillya, M.W.; Montagut-Bordas, C.; Lee, B.; Hell, J.W.; Horne, M.C. alpha-Actinin Promotes Surface Localization and Current Density of the $\mathrm{Ca}^{2+}$ Channel Cav 1.2 by Binding to the IQ Region of the alpha1 Subunit. Biochemistry 2017, 56, 3669-3681. [CrossRef]

79. Jovic, M.; Sharma, M.; Rahajeng, J.; Caplan, S. The early endosome: A busy sorting station for proteins at the crossroads. Histol. Histopathol. 2010, 25, 99-112. [CrossRef]

80. Rougier, J.S.; Albesa, M.; Abriel, H. Ubiquitylation and SUMOylation of cardiac ion channels. J. Cardiovasc. Pharmacol. 2010, 56, 22-28. [CrossRef]

81. Mukhopadhyay, D.; Riezman, H. Proteasome-independent functions of ubiquitin in endocytosis and signaling. Science 2007, 315, 201-205. [CrossRef]

82. Best, J.M.; Foell, J.D.; Buss, C.R.; Delisle, B.P.; Balijepalli, R.C.; January, C.T.; Kamp, T.J. Small GTPase Rab11b regulates degradation of surface membrane L-type Cav1.2 channels. Am. J. Physiol. Cell Physiol. 2011, 300, C1023-C1033. [CrossRef]

83. Rougier, J.S.; Albesa, M.; Abriel, H.; Viard, P. Neuronal precursor cell-expressed developmentally down-regulated 4-1 (NEDD4-1) controls the sorting of newly synthesized Ca 1.2 calcium channels. J. Biol. Chem. 2011, 286, 8829-8838. [CrossRef]

84. Moshal, K.S.; Roder, K.; Kabakov, A.Y.; Werdich, A.A.; Chiang, D.Y.; Turan, N.N.; Xie, A.; Kim, T.Y.; Cooper, L.L.; Lu, Y.; et al. LITAF (Lipopolysaccharide-Induced Tumor Necrosis Factor) Regulates Cardiac L-Type Calcium Channels by Modulating NEDD (Neural Precursor Cell Expressed Developmentally Downregulated Protein) 4-1 Ubiquitin Ligase. Circ. Genom. Precis. Med. 2019, 12, 407-420. [CrossRef]

85. Morgenstern, T.J.; Park, J.; Fan, Q.R.; Colecraft, H.M. A potent voltage-gated calcium channel inhibitor engineered from a nanobody targeted to auxiliary Ca $a_{V}$ beta subunits. eLife 2019, 8. [CrossRef] [PubMed] 
86. Soeller, C.; Cannell, M.B. Examination of the transverse tubular system in living cardiac rat myocytes by 2-photon microscopy and digital image-processing techniques. Circ. Res. 1999, 84, 266-275. [CrossRef]

87. Hong, T.; Shaw, R.M. Cardiac T-Tubule Microanatomy and Function. Physiol. Rev. 2017, 97, 227-252. [CrossRef] [PubMed]

88. Bers, D.M. Excitation-Contraction Coupling and Cardiac Contractile Force; Springer Science \& Business Media: Dordrecht, The Netherlands, 2001; p. 427.

89. Scriven, D.R.; Asghari, P.; Schulson, M.N.; Moore, E.D. Analysis of $\mathrm{Ca}_{\mathrm{V}} 1.2$ and ryanodine receptor clusters in rat ventricular myocytes. Biophys. J. 2010, 99, 3923-3929. [CrossRef]

90. Pasek, M.; Brette, F.; Nelson, A.; Pearce, C.; Qaiser, A.; Christe, G.; Orchard, C.H. Quantification of t-tubule area and protein distribution in rat cardiac ventricular myocytes. Prog. Biophys. Mol. Biol. 2008, 96, 244-257. [CrossRef]

91. Song, L.S.; Sobie, E.A.; McCulle, S.; Lederer, W.J.; Balke, C.W.; Cheng, H. Orphaned ryanodine receptors in the failing heart. Proc. Natl. Acad. Sci. USA 2006, 103, 4305-4310. [CrossRef] [PubMed]

92. Gomez, A.M.; Valdivia, H.H.; Cheng, H.; Lederer, M.R.; Santana, L.F.; Cannell, M.B.; McCune, S.A.; Altschuld, R.A.; Lederer, W.J. Defective excitation-contraction coupling in experimental cardiac hypertrophy and heart failure. Science 1997, 276, 800-806. [CrossRef]

93. Cheng, H.; Lederer, M.R.; Lederer, W.J.; Cannell, M.B. Calcium sparks and $\left[\mathrm{Ca}^{2+}\right]_{\mathrm{i}}$ waves in cardiac myocytes. Am. J. Physiol. 1996, 270, C148-C159. [CrossRef]

94. Lu, F.; Pu, W.T. The architecture and function of cardiac dyads. Biophys. Rev. 2020, 12, 1007-1017. [CrossRef]

95. Louch, W.E.; Mork, H.K.; Sexton, J.; Stromme, T.A.; Laake, P.; Sjaastad, I.; Sejersted, O.M. T-tubule disorganization and reduced synchrony of $\mathrm{Ca}^{2+}$ release in murine cardiomyocytes following myocardial infarction. J. Physiol. 2006, 574, 519-533. [CrossRef]

96. Nikolaev, V.O.; Moshkov, A.; Lyon, A.R.; Miragoli, M.; Novak, P.; Paur, H.; Lohse, M.J.; Korchev, Y.E.; Harding, S.E.; Gorelik, J. Beta2-adrenergic receptor redistribution in heart failure changes cAMP compartmentation. Science 2010, 327, $1653-1657$. [CrossRef]

97. Harvey, R.D.; Hell, J.W. Cav1.2 signaling complexes in the heart. J. Mol. Cell Cardiol. 2013, 58, 143-152. [CrossRef]

98. Chen-Izu, Y.; Xiao, R.P.; Izu, L.T.; Cheng, H.; Kuschel, M.; Spurgeon, H.; Lakatta, E.G. $G_{i}$-dependent localization of $\beta_{2}$-adrenergic receptor signaling to L-type $\mathrm{Ca}^{2+}$ channels. Biophys. J. 2000, 79, 2547-2556. [CrossRef]

99. Hong, T.; Yang, H.; Zhang, S.S.; Cho, H.C.; Kalashnikova, M.; Sun, B.; Zhang, H.; Bhargava, A.; Grabe, M.; Olgin, J.; et al. Cardiac BIN1 folds T-tubule membrane, controlling ion flux and limiting arrhythmia. Nat. Med. 2014, 20, 624-632. [CrossRef]

100. Caldwell, J.L.; Smith, C.E.R.; Taylor, R.F.; Kitmitto, A.; Eisner, D.A.; Dibb, K.M.; Trafford, A.W. Dependence of Cardiac Transverse Tubules on the BAR Domain Protein Amphiphysin II (BIN-1). Circ. Res. 2014, 115, 986-996. [CrossRef] [PubMed]

101. De La Mata, A.; Tajada, S.; O’Dwyer, S.; Matsumoto, C.; Dixon, R.E.; Hariharan, N.; Moreno, C.M.; Santana, L.F. BIN1 Induces the Formation of T-Tubules and Adult-Like Ca ${ }^{2+}$ Release Units in Developing Cardiomyocytes. Stem Cells 2019, 37, 54-64. [CrossRef] [PubMed]

102. Hong, T.T.; Smyth, J.W.; Chu, K.Y.; Vogan, J.M.; Fong, T.S.; Jensen, B.C.; Fang, K.; Halushka, M.K.; Russell, S.D.; Colecraft, H.; et al BIN1 is reduced and Cav1.2 trafficking is impaired in human failing cardiomyocytes. Heart Rhythm 2012, 9, 812-820. [CrossRef]

103. D'Alessandro, M.; Hnia, K.; Gache, V.; Koch, C.; Gavriilidis, C.; Rodriguez, D.; Nicot, A.S.; Romero, N.B.; Schwab, Y.; Gomes, E.; et al. Amphiphysin 2 Orchestrates Nucleus Positioning and Shape by Linking the Nuclear Envelope to the Actin and Microtubule Cytoskeleton. Dev. Cell 2015, 35, 186-198. [CrossRef]

104. Meunier, B.; Quaranta, M.; Daviet, L.; Hatzoglou, A.; Leprince, C. The membrane-tubulating potential of amphiphysin 2/BIN1 is dependent on the microtubule-binding cytoplasmic linker protein 170 (CLIP-170). Eur. J. Cell Biol. 2009, 88, 91-102. [CrossRef]

105. Yashirogi, S.; Nagao, T.; Nishida, Y.; Takahashi, Y.; Qaqorh, T.; Yazawa, I.; Katayama, T.; Kioka, H.; Matsui, T.S.; Saito, S.; et al. AMPK regulates cell shape of cardiomyocytes by modulating turnover of microtubules through CLIP-170. EMBO Rep. 2021, 22, e50949. [CrossRef] [PubMed]

106. Drager, N.M.; Nachman, E.; Winterhoff, M.; Bruhmann, S.; Shah, P.; Katsinelos, T.; Boulant, S.; Teleman, A.A.; Faix, J.; Jahn, T.R. Bin1 directly remodels actin dynamics through its BAR domain. EMBO Rep. 2017, 18, 2051-2066. [CrossRef] [PubMed]

107. Yamada, H.; Padilla-Parra, S.; Park, S.J.; Itoh, T.; Chaineau, M.; Monaldi, I.; Cremona, O.; Benfenati, F.; De Camilli, P.; Coppey-Moisan, M.; et al. Dynamic interaction of amphiphysin with N-WASP regulates actin assembly. J. Biol. Chem. 2009, 284, 34244-34256. [CrossRef]

108. Takenawa, T.; Suetsugu, S. The WASP-WAVE protein network: Connecting the membrane to the cytoskeleton. Nat. Rev. Mol. Cell Biol. 2007, 8, 37-48. [CrossRef] [PubMed]

109. Leach, R.N.; Desai, J.C.; Orchard, C.H. Effect of cytoskeleton disruptors on L-type Ca channel distribution in rat ventricular myocytes. Cell Calcium 2005, 38, 515-526. [CrossRef] [PubMed]

110. Tian, Q.; Pahlavan, S.; Oleinikow, K.; Jung, J.; Ruppenthal, S.; Scholz, A.; Schumann, C.; Kraegeloh, A.; Oberhofer, M.; Lipp, P.; et al. Functional and morphological preservation of adult ventricular myocytes in culture by sub-micromolar cytochalasin $\mathrm{D}$ supplement. J. Mol. Cell Cardiol. 2012, 52, 113-124. [CrossRef]

111. Dixon, R.E.; Hong, T.T.; Shaw, R.M.; Santana, L.F. Bin1 Regulates Cav1.2 Channel Clustering in Ventricular Myocytes. Biophys. J. 2016, 110, 441a-442a. [CrossRef]

112. Itoh, T.; Erdmann, K.S.; Roux, A.; Habermann, B.; Werner, H.; De Camilli, P. Dynamin and the actin cytoskeleton cooperatively regulate plasma membrane invagination by BAR and F-BAR proteins. Dev. Cell 2005, 9, 791-804. [CrossRef] 
113. Smyth, J.W.; Vogan, J.M.; Buch, P.J.; Zhang, S.S.; Fong, T.S.; Hong, T.T.; Shaw, R.M. Actin cytoskeleton rest stops regulate anterograde traffic of connexin 43 vesicles to the plasma membrane. Circ. Res. 2012, 110, 978-989. [CrossRef]

114. Wittmann, T.; Bokoch, G.M.; Waterman-Storer, C.M. Regulation of leading edge microtubule and actin dynamics downstream of Rac1. J. Cell Biol. 2003, 161, 845-851. [CrossRef]

115. Bartolini, F.; Ramalingam, N.; Gundersen, G.G. Actin-capping protein promotes microtubule stability by antagonizing the actin activity of mDia1. Mol. Biol. Cell 2012, 23, 4032-4040. [CrossRef]

116. Basheer, W.A.; Shaw, R.M. Connexin 43 and Cav1.2 Ion Channel Trafficking in Healthy and Diseased Myocardium. Circ. Arrhythm. Electrophysiol. 2016, 9, e001357. [CrossRef]

117. Balijepalli, R.C.; Foell, J.D.; Hall, D.D.; Hell, J.W.; Kamp, T.J. Localization of cardiac L-type Ca ${ }^{2+}$ channels to a caveolar macromolecular signaling complex is required for $\beta 2$-adrenergic regulation. Proc. Natl. Acad. Sci. USA 2006, 103, 7500-7505. [CrossRef]

118. Balijepalli, R.C.; Kamp, T.J. Caveolae, ion channels and cardiac arrhythmias. Prog. Biophys. Mol. Biol. 2008, 98, 149-160. [CrossRef] [PubMed]

119. Brette, F.; Orchard, C. T-tubule function in mammalian cardiac myocytes. Circ. Res. 2003, 92, 1182-1192. [CrossRef] [PubMed]

120. Levin, K.R.; Page, E. Quantitative studies on plasmalemmal folds and caveolae of rabbit ventricular myocardial cells. Circ. Res. 1980, 46, 244-255. [CrossRef] [PubMed]

121. Calaghan, S.; White, E. Caveolae modulate excitation-contraction coupling and beta2-adrenergic signalling in adult rat ventricular myocytes. Cardiovasc. Res. 2006, 69, 816-824. [CrossRef] [PubMed]

122. Correll, R.N.; Makarewich, C.A.; Zhang, H.Y.; Zhang, C.; Sargent, M.A.; York, A.J.; Berretta, R.M.; Chen, X.W.; Houser, S.R.; Molkentin, J.D. Caveolae-localized L-type $\mathrm{Ca}^{2+}$ channels do not contribute to function or hypertrophic signalling in themouse heart. Cardiovasc. Res. 2017, 113, 749-759. [CrossRef]

123. Catalucci, D.; Zhang, D.H.; DeSantiago, J.; Aimond, F.; Barbara, G.; Chemin, J.; Bonci, D.; Picht, E.; Rusconi, F.; Dalton, N.D.; et al. Akt regulates L-type $\mathrm{Ca}^{2+}$ channel activity by modulating $\mathrm{Ca}_{\mathrm{V}} \alpha_{1}$ protein stability. J. Cell Biol. 2009, 184, 923-933. [CrossRef]

124. Sato, D.; Hernandez-Hernandez, G.; Matsumoto, C.; Tajada, S.; Moreno, C.M.; Dixon, R.E.; O’Dwyer, S.; Navedo, M.F.; Trimmer, J.S.; Clancy, C.E.; et al. A stochastic model of ion channel cluster formation in the plasma membrane. J. Gen. Physiol. 2019. [CrossRef]

125. Eggers, C.T.; Schafer, J.C.; Goldenring, J.R.; Taylor, S.S. D-AKAP2 interacts with Rab4 and Rab11 through its RGS domains and regulates transferrin receptor recycling. J. Biol. Chem. 2009, 284, 32869-32880. [CrossRef]

126. Neumann, S.A.; Tingley, W.G.; Conklin, B.R.; Shrader, C.J.; Peet, E.; Muldoon, M.F.; Jennings, J.R.; Ferrell, R.E.; Manuck, S.B AKAP10 (I646V) functional polymorphism predicts heart rate and heart rate variability in apparently healthy, middle-aged European-Americans. Psychophysiology 2009, 46, 466-472. [CrossRef]

127. Reuter, H.; Scholz, H. The regulation of the calcium conductance of cardiac muscle by adrenaline. J. Physiol. 1977, $264,49-62$. [CrossRef]

128. Yue, D.T.; Herzig, S.; Marban, E. Beta-adrenergic stimulation of calcium channels occurs by potentiation of high-activity gating modes. Proc. Natl. Acad. Sci. USA 1990, 87, 753-757. [CrossRef] [PubMed]

129. Sperelakis, N.; Schneider, J.A. A metabolic control mechanism for calcium ion influx that may protect the ventricular myocardial cell. Am. J. Cardiol. 1976, 37, 1079-1085. [CrossRef]

130. Bean, B.P.; Nowycky, M.C.; Tsien, R.W. Beta-adrenergic modulation of calcium channels in frog ventricular heart cells. Nature 1984, 307, 371-375. [CrossRef] [PubMed]

131. Tsien, R.W.; Bean, B.P.; Hess, P.; Lansman, J.B.; Nilius, B.; Nowycky, M.C. Mechanisms of calcium channel modulation by beta-adrenergic agents and dihydropyridine calcium agonists. J. Mol. Cell Cardiol. 1986, 18, 691-710. [CrossRef]

132. Diering, G.H.; Huganir, R.L. The AMPA Receptor Code of Synaptic Plasticity. Neuron 2018, 100, 314-329. [CrossRef] [PubMed]

133. Nedvetsky, P.I.; Stefan, E.; Frische, S.; Santamaria, K.; Wiesner, B.; Valenti, G.; Hammer, J.A., 3rd; Nielsen, S.; Goldenring, J.R.; Rosenthal, W.; et al. A Role of myosin Vb and Rab11-FIP2 in the aquaporin-2 shuttle. Traffic 2007, 8, 110-123. [CrossRef] [PubMed]

134. Fushimi, K.; Sasaki, S.; Marumo, F. Phosphorylation of serine 256 is required for cAMP-dependent regulatory exocytosis of the aquaporin-2 water channel. J. Biol. Chem. 1997, 272, 14800-14804. [CrossRef] [PubMed]

135. Bao, L.; Hadjiolova, K.; Coetzee, W.A.; Rindler, M.J. Endosomal KATP channels as a reservoir after myocardial ischemia: A role for SUR2 subunits. Am. J. Physiol. Heart Circ. Physiol. 2011, 300, H262-H270. [CrossRef] [PubMed]

136. Seebohm, G.; Strutz-Seebohm, N.; Birkin, R.; Dell, G.; Bucci, C.; Spinosa, M.R.; Baltaev, R.; Mack, A.F.; Korniychuk, G.; Choudhury, A.; et al. Regulation of endocytic recycling of KCNQ1/KCNE1 potassium channels. Circ. Res. 2007, 100, 686-692. [CrossRef]

137. Wang, Y.; Zankov, D.P.; Jiang, M.; Zhang, M.; Henderson, S.C.; Tseng, G.N. $\left[\mathrm{Ca}^{2+}\right]_{\mathrm{i}}$ elevation and oxidative stress induce KCNQ1 protein translocation from the cytosol to the cell surface and increase slow delayed rectifier $\left(\mathrm{I}_{\mathrm{Ks}}\right)$ in cardiac myocytes. J. Biol. Chem. 2013, 288, 35358-35371. [CrossRef] [PubMed]

138. Hermosilla, T.; Encina, M.; Morales, D.; Moreno, C.; Conejeros, C.; Alfaro-Valdes, H.M.; Lagos-Meza, F.; Simon, F.; Altier, C.; Varela, D. Prolonged $\mathrm{AT}_{1} \mathrm{R}$ activation induces $\mathrm{Ca}_{\mathrm{V}} 1.2$ channel internalization in rat cardiomyocytes. Sci. Rep. 2017, 7, 10131. [CrossRef]

139. Diering, G.H.; Heo, S.; Hussain, N.K.; Liu, B.; Huganir, R.L. Extensive phosphorylation of AMPA receptors in neurons. Proc. Natl. Acad. Sci. USA 2016, 113, E4920-E4927. [CrossRef] 
140. Makino, Y.; Johnson, R.C.; Yu, Y.; Takamiya, K.; Huganir, R.L. Enhanced synaptic plasticity in mice with phosphomimetic mutation of the GluA1 AMPA receptor. Proc. Natl. Acad. Sci. USA 2011, 108, 8450-8455. [CrossRef]

141. Olivito, L.; Saccone, P.; Perri, V.; Bachman, J.L.; Fragapane, P.; Mele, A.; Huganir, R.L.; De Leonibus, E. Phosphorylation of the AMPA receptor GluA1 subunit regulates memory load capacity. Brain Struct. Funct. 2016, 221, 591-603. [CrossRef]

142. Lee, H.K.; Kameyama, K.; Huganir, R.L.; Bear, M.F. NMDA induces long-term synaptic depression and dephosphorylation of the GluR1 subunit of AMPA receptors in hippocampus. Neuron 1998, 21, 1151-1162. [CrossRef]

143. Poulet, C.; Sanchez-Alonso, J.; Swiatlowska, P.; Mouy, F.; Lucarelli, C.; Alvarez-Laviada, A.; Gross, P.; Terracciano, C.; Houser, S.; Gorelik, J. Junctophilin-2 tethers T-tubules and recruits functional L-type calcium channels to lipid rafts in adult cardiomyocytes. Cardiovasc. Res. 2021, 117, 149-161. [CrossRef] [PubMed]

144. Sanchez-Alonso, J.L.; Loucks, A.; Schobesberger, S.; van Cromvoirt, A.M.; Poulet, C.; Chowdhury, R.A.; Trayanova, N.; Gorelik, J. Nanoscale regulation of L-type calcium channels differentiates between ischemic and dilated cardiomyopathies. EBioMedicine 2020, 57, 102845. [CrossRef] [PubMed]

145. Bryant, S.M.; Kong, C.H.; Watson, J.; Cannell, M.B.; James, A.F.; Orchard, C.H. Altered distribution of $\mathrm{I}_{\mathrm{Ca}}$ impairs Ca release at the t-tubules of ventricular myocytes from failing hearts. J. Mol. Cell Cardiol. 2015, 86, 23-31. [CrossRef]

146. Sanchez-Alonso, J.L.; Bhargava, A.; O’Hara, T.; Glukhov, A.V.; Schobesberger, S.; Bhogal, N.; Sikkel, M.B.; Mansfield, C.; Korchev, Y.E.; Lyon, A.R.; et al. Microdomain-Specific Modulation of L-Type Calcium Channels Leads to Triggered Ventricular Arrhythmia in Heart Failure. Circ. Res. 2016, 119, 944-955. [CrossRef] [PubMed]

147. Lakatta, E.G. Cardiovascular regulatory mechanisms in advanced age. Physiol. Rev. 1993, 73, 413-467. [CrossRef] [PubMed]

148. Josephson, I.R.; Guia, A.; Stern, M.D.; Lakatta, E.G. Alterations in properties of L-type Ca channels in aging rat heart. J. Mol. Cell Cardiol. 2002, 34, 297-308. [CrossRef]

149. Hatch, F.; Lancaster, M.K.; Jones, S.A. Aging is a primary risk factor for cardiac arrhythmias: Disruption of intracellular Ca ${ }^{2+}$ regulation as a key suspect. Expert Rev. Cardiovasc. Ther. 2011, 9, 1059-1067. [CrossRef]

150. Boncompain, G.; Divoux, S.; Gareil, N.; de Forges, H.; Lescure, A.; Latreche, L.; Mercanti, V.; Jollivet, F.; Raposo, G.; Perez, F. Synchronization of secretory protein traffic in populations of cells. Nat. Methods 2012, 9, 493-498. [CrossRef]

151. Evans, A.J.; Gurung, S.; Wilkinson, K.A.; Stephens, D.J.; Henley, J.M. Assembly, Secretory Pathway Trafficking, and Surface Delivery of Kainate Receptors Is Regulated by Neuronal Activity. Cell Rep. 2017, 19, 2613-2626. [CrossRef]

152. Wilson, Z.T.; Jiang, M.; Geng, J.; Kaur, S.; Workman, S.W.; Hao, J.; Bernas, T.; Tseng, G.N. Delayed KCNQ1/KCNE1 assembly on the cell surface helps IKs fulfill its function as a repolarization reserve in the heart. J. Physiol. 2021. [CrossRef]

153. Kutchukian, C.; Vivas, O.; Casas, M.; Jones, J.G.; Tiscione, S.A.; Simo, S.; Ory, D.S.; Dixon, R.E.; Dickson, E.J. NPC1 regulates the distribution of phosphatidylinositol 4-kinases at Golgi and lysosomal membranes. EMBO J. 2021, e105990. [CrossRef]

154. Fu, Y.; Shaw, S.A.; Naami, R.; Vuong, C.L.; Basheer, W.A.; Guo, X.; Hong, T. Isoproterenol Promotes Rapid Ryanodine Receptor Movement to Bridging Integrator 1 (BIN1)-Organized Dyads. Circulation 2016, 133, 388-397. [CrossRef] [PubMed]

155. Eichel, C.A.; Rios-Perez, E.B.; Liu, F.; Jameson, M.B.; Jones, D.K.; Knickelbine, J.J.; Robertson, G.A. A microtranslatome coordinately regulates sodium and potassium currents in the human heart. eLife 2019, 8. [CrossRef] [PubMed]

156. Dixon, R.E.; Cheng, E.P.; Mercado, J.L.; Santana, L.F. L-type $\mathrm{Ca}^{2+}$ channel function during Timothy syndrome. Trends Cardiovasc. Med. 2012, 22, 72-76. [CrossRef]

157. Sato, D.; Dixon, R.E.; Santana, L.F.; Navedo, M.F. A model for cooperative gating of L-type Ca ${ }^{2+}$ channels and its effects on cardiac alternans dynamics. PLoS Comput. Biol. 2018, 14, e1005906. [CrossRef] 